\title{
The evolution of the Carpathian Foredeep Basin during the latest Badenian and Sarmatian (Middle Miocene): inferences from micropalaeontological data
}

\author{
Simina Dumitrița DUMITRIU ${ }^{1, *}$ Zofia DUBICKA ${ }^{2}$, Sergiu LOGHIN ${ }^{1}$, \\ Mihaela Carmen MELINTE-DOBRINESCU ${ }^{3}$ and Jolanta PARUCH-KULCZYCKA ${ }^{4}$ \\ 1 Alexandru loan Cuza University of lasi, Department of Geology, Carol I Blvd., 20A, 700505 laşi, Romania \\ 2 University of Warsaw, Faculty of Geology, Żwirki i Wigury 93, 02-089 Warszawa, Poland \\ 3 National Institute of Marine Geology and Geo-Ecology (GeoEcoMar), 23-25 Dimitrie Onciul, 024053 Bucharest, Romania \\ 4 Polish Geological Institute - National Research Institute, Rakowiecka 4, 00-975 Warszawa, Poland
}

Dumitriu, S.D., Dubicka, Z., Loghin, S., Melinte-Dobrinescu, M.C., Paruch-Kulczycka, J., 2020. The evolution of the Carpathian Foredeep Basin during the latest Badenian and Sarmatian (Middle Miocene): inferences from micropalaeontological data. Geological Quarterly, 64 (4): 1004-1022, doi: 10.7306/gq.1568

Seven Middle Miocene (Upper Badenian to Lower Sarmatian) sedimentary sections of the Central Paratethys, two from the Polish Carpathian Foredeep Basin (PCFB) and five from the Eastern Carpathian Foreland Basin (ECFB) of Romania and the Republic of Moldova have been analysed micropalaeontologically to better constrain the Badenian-Sarmatian Extinction Event, characterized by significant taxonomic impoverishment of both foraminifers and ostracods. Our studies show significant palaeoenvironmental changes in the basin including depth, salinity, oxygenation, and organic matter flux. The occurrence of moderately diverse planktonic foraminifera (Globigerina, Globigerinita, Globorotalia, Trilobatus, Orbulina, Velapertina) in the Upper Badenian deposits of the PCFB as well as in the ECFB and their rarity in the lowermost Sarmatian indicate an almost fully marine environment during the latest Badenian, followed by a significant regression and possible appearance of much more restricted marine conditions across the boundary. The taxonomic composition of the Sarmatian foraminifera, ostracoda and calcareous nannofossils indicate that during this interval the salinity fluctuated strongly, with the water regime varying from brackish to normal marine. In addition, the identified micropalaeontological assemblages identified show palaeoenvironmental similarity across different basins of the Central Paratethys. This supports a hypothesis of possible connections during the latest Badenian between different areas of the Central Paratethys, as well as of the existence of a gateway between the Central Paratethys and the Mediterranean realm.

Key words: Middle Miocene, Carpathian Foredeep Basin, foraminifera, ostracoda, nannofossils, palaeoenvironment

\section{INTRODUCTION}

The Paratethys Sea was formed in the Early Oligocene as a result of collision between the Afro-Arabian Plate and the Eurasian Plate (Steininger and Rögl, 1985; Seneš, 1988). The Paratethys is subdivided into three basins: the Western Paratethys (Alpine region), the Central Paratethys (Carpathians, Balkans) and the Eastern Paratethys (Euxinian-Caspian) (Seneš, 1960). The strata of the Central Paratethys cover wide areas of the Carpathian Foredeep from Austria, via Poland towards the north and continue along Ukraine, Romania and the Republic of Moldova to the east (Fig. 1).

Variable palaeoenvironmental conditions in the Paratethys resulting in different facies development were strongly influenced by temporary connections with the Mediterranean and

\footnotetext{
* Corresponding author, e-mail: siminadumitriu@gmail.com Received: February 5, 2020; accepted: October 7, 2020; first published online: November 13, 2020
}

the Indo-Pacific realms (Popescu, 1975; Rögl and Steininger, 1984; Paramonova, 1995; Rögl, 1998, 1999; Iljina, 2000; Kováč, 2000; Popov et al., 2004, 2005; Nevesskaja et al., 2006; Harzhauser and Piller, 2007; Harzhauser et al., 2007; Studencka and Jasionowski, 2011; Maissuradze et al., 2014; Kováč et al., 2017). Moreover, changes in palaeoclimate, stratification of the water column, nutrient supply, as well as bottom-water oxygen have been recognized in different areas of the Central Paratethys (Gonera et al., 2000; Bicchi et al., 2003; Hudáčková et al., 2003, 2018; Filipescu et al., 2005; Báldi, 2006; Kováč et al., 2007, 2017; Kováčová and Hudáčková, 2009; Kováčová et al., 2009; Peryt et al., 2014). The connection between the Central Paratethys and Mediterranean regions is believed to have closed at some point in the Middle Miocene.

During the mid-Badenian, large-scale evaporitic sedimentation (known also as the Badenian salinity crisis; de Leeuw et al., 2010), was widespread in a large part of the Central Paratethys, namely in the Carpathian Foredeep, from south-east Poland to Romania (Peryt, 2006). Afterwards, a transgression took place across the whole of the Central and Eastern Paratethys during the Late Badenian (= the Konkian stage in the Eastern Paratethys) (Rögl and Müller, 1976; Rögl, 1999; Krzywiec, 2001; 


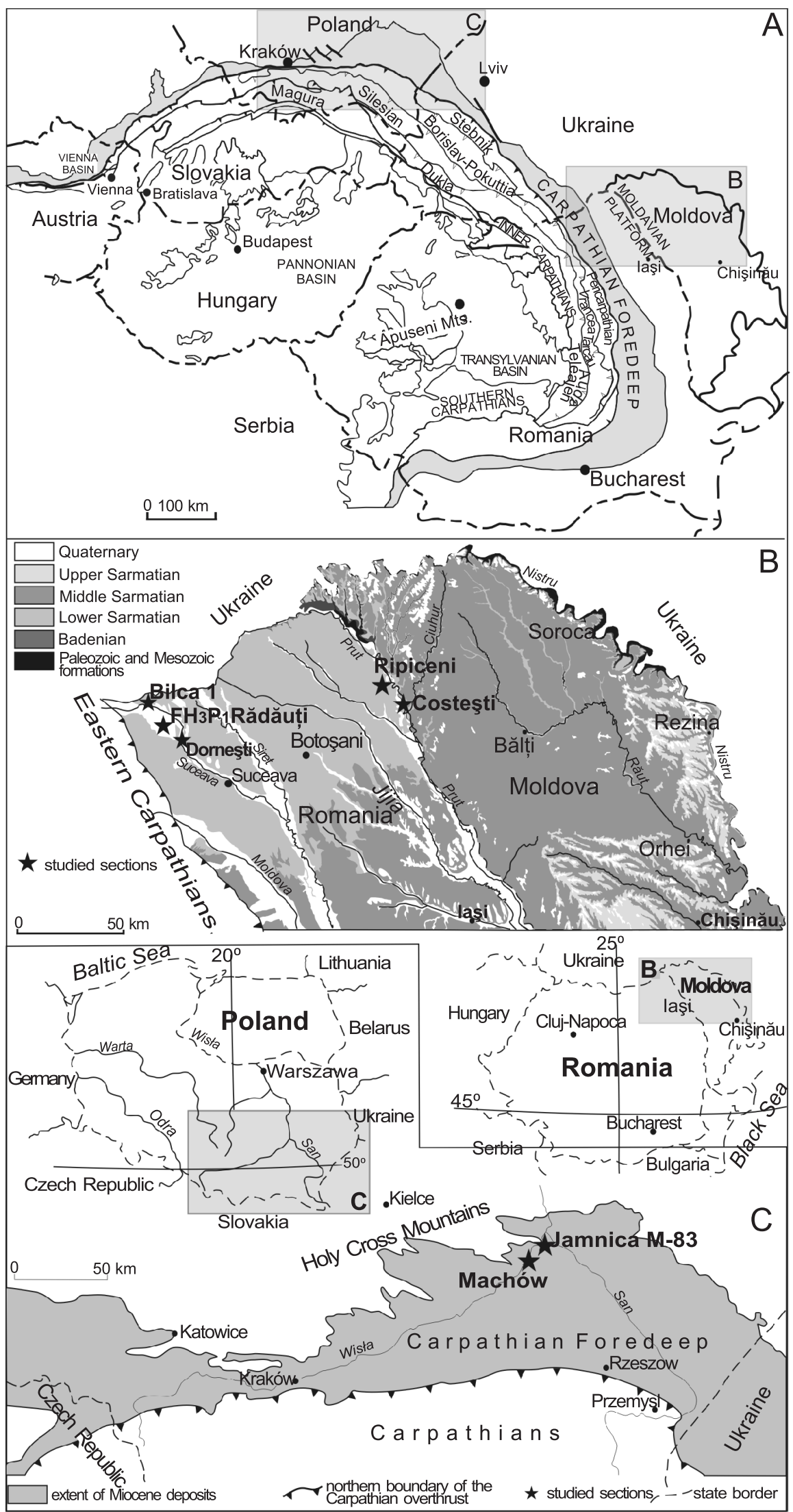

Fig. 1. Map of the study areas (modified after Dumitriu et al., 2017)

A - simplified geological sketch map of the Carpathian Foredeep and Carpathian Orogen (modified after Pawlewicz, 2006); B - simplified geological sketch map of northeastern Romania and the northwestern Republic of Moldova (modified after the geological maps of Romania and Moldova, scale 1:200,000); location of the Romanian ( $\mathrm{FH}_{3} \mathrm{P}_{1}$ Rădăuţi, Bilca 1, Dorneşti and Ripiceni) and Moldovian (Costeşti) sections studied; $\mathbf{C}$ - location of the Polish sections studied (Machów and Jamnica M-83 core) and the extension of the Miocene deposits into extra-Carpathian Poland (modified after Ney et al., 1974) 
Popov et el., 2004; Oszczypko et al., 2006; Kováč et al., 2007) and a normal marine environment was re-established. In the Central Paratethys this transgression is postulated to have been generally controlled by a global eustatic sea level rise (Kováč et al., 2007). The latest Badenian is considered to be the last fully marine interval in the Central Paratethys (Kováč et al., 2007) and possibly marks the last connection between the Paratethys Sea and the Mediterranean realm. However, this interpretation has been questioned in other studies (e.g., Studencka et al., 1998; Bartol et al., 2012, 2014), which postulated some brief connections also during the Sarmatian. Affinities with the Indo-Pacific region during the Sarmatian have also been proposed (e.g., Filipescu and Silye, 2008; Silye, 2015).

In this paper we provide quantitative and qualitative foraminiferal and ostracod data, obtained from 172 sediment samples from seven sections of various areas of the Central Paratethys in Poland, Romania and Republic of Moldova. Nannofossils have been additionally studied from selected samples. Based upon newly collected data and compiled datasets of previously published foraminiferal and ostracod studies, we discuss palaeoenvironmental changes in the Central Paratethys, especially concerning the Carpathian Foreland Basin during the latest Badenian and Sarmatian, including palaeogeography, sea level changes, salinity and oxygenation.

\section{GEOLOGICAL SETTING AND STRATIGRAPHY}

The micropalaeontological data provided in this study has been collected from four exposures and three borehole cores in Poland, Romania and the Republic of Moldova (Fig. 1A). The sections investigated in Romania are the $\mathrm{FH}_{3} \mathrm{P}_{1}$ Rădăuți

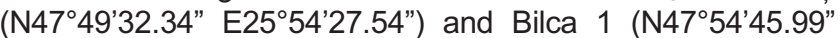
E25 $\left.43^{\prime} 33.11^{\prime \prime}\right)$ cores and the Dorneşti (N47 52 '52.1" E25 $\left.5^{\circ} 2^{\prime} 3.4^{\prime \prime}\right)$ and Ripiceni (N47 $58^{\prime} 50^{\prime \prime}$ E2 $\left.7^{\circ} 6^{\prime} 7.3^{\prime \prime}\right)$ exposures, which are located in northeastern Romania (Fig. 1B), while the Polish sections are in the historical Machów sulphur mine (N50³1'59.60" E21 $\left.1^{\circ} 39^{\prime} 43.47^{\prime \prime}\right)$ and the Jamnica M-83 (N50 $36^{\prime} 40.18^{\prime \prime}$ E2 $1^{\circ} 58^{\prime} 15.50^{\prime \prime}$ ) core, both situated in southeastern Poland (Fig. 1C). The section in the Moldova (Costeşti

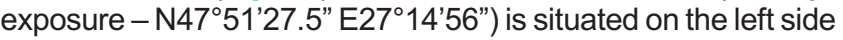
of the Prut River, near the Stânca-Costeşti Lake in the northwestern part of Moldova (Fig. 1B). The material from the Machów, Jamnica M-83, $\mathrm{FH}_{3} \mathrm{P}_{1}$ Rădăuți, Dorneşti, and Costeşti sections have been already published in Dumitriu et al. (2017) as regards the biostratigraphical position of the successions based on foraminifera, ostracoda and calcareous nannoplankton assemblages, while the present paper focuses on palaeoenvironmental interpretation.

During the Middle Miocene, all areas studied areas were part of the Paratethyan domain (Popov et al., 2004). The strata studied were deposited in the Carpathian Foreland Basin which was developed as a typical foreland basin related to Carpathian frontal movement (Oszczypko and Oszczypko-Clowes, 2012) resulting from the flexural subsidence of a craton under an orogenic belt (DeCelles and Gilles, 1996; Fig. 1A). The deposits studied of the Machów, Jamnica $\mathrm{M}-83, \mathrm{FH}_{3} \mathrm{P}_{1}$ Rădăuți, Bilca 1 and Dorneşti successions are interpreted as having accumulated in a foredeep depozone of a foreland basin (Oszczypko, 1998; Grasu et al., 2002; Oszczypko and Oszczypko-Clowes, 2012) while the strata of the Ripiceni and Costeşti sections belong to the backbulge depozone (more external part of the basin) of the foreland basin system of the Eastern Carpathians (Grasu et al., 2002).

\section{POLISH CARPATHIAN FOREDEEP BASIN}

The Polish Carpathian Foredeep Basin is filled with Middle Miocene (Badenian and Sarmatian) marine deposits, which range from a few hundred metres thick in its northern-marginal part, up to $3000 \mathrm{~m}$ in the southeastern zone (more central part of the basin; Ney et al., 1974). The Machów section is represented mostly by clays with marl intercalations in the lower part, which are followed by sandstones, and clays with mudstone intercalations, in the upper part. Similar lithologies are encountered in the Jamnica M-83 core with the exception of sandstones which are not present in this borehole. All these deposits belong to the Machów Formation, which includes three subunits: the Pecten Beds, Syndesmia Beds and Krakowiec Clays (Alexandrowicz et al., 1982).

The Pecten Beds have been dated as Upper Badenian by Odrzywolska-Bieńkowa (1966) based on microfaunal assemblages of Hanzawaia crassiseptata (Łuczkowska), Sphaerodina bulloides d'Orbigny, Bulimina aculeata d'Orbigny, $B$. insignis Łuczkowska and numerous specimens of Spirialis (Łuczkowska, 1964). Based on micropalaeontological analyses, the Krakowiec Clays have been assigned to the foraminiferal Anomalinoides dividens and Elphidium hauerinum zones (Odrzywolska-Bieńkowa, 1972; Łuczkowska, 1972; Olszewska, 1999; Krzywiec et al., 2008; Lelek et al., 2010; Dumitriu et al., 2017) as well as the B-E Assemblages Zones sensu Dumitriu et al. (2017) indicating the Lower Sarmatian. This stratigraphic position is supported by studies on calcareous nannofossils by Peryt (1997) and Garecka and Olszewska (2011), who distinguished the upper part of the NN6 Zone and the NN7 zone in the "Krakowiec Clays".

\section{EASTERN CARPATHIANS FORELAND BASIN (ROMANIA AND REPUBLIC OF MOLDOVA)}

The deposits studied from Romania and the Republic of Moldova belongs to the western part of the Eastern European Platform (Ionesi and Ionesi, 1968; Ionesi, 1968, 1994; Ionesi et al., 2005). They are situated in the external part of the Eastern Carpathians (accumulated in the Carpathian Foreland Basin) and belong to the last marine depositional cycle of the Moldavian Platform (Ionesi, 1994). Their geometry is characterized by a significant increase in thickness of the Volhynian strata (Lower Sarmatian sensu lato, Barbot de Marny, 1866), as a consequence of the approaching Carpathian orogeny i.e., the deposit thickness is $\sim 500 \mathrm{~m}$ between the Moldova and Siret rivers and reaches up to $800 \mathrm{~m}$ in front of the Carpathian orogen (lonesi, 1968, 1994).

The strata of the $\mathrm{FH}_{3} \mathrm{P}_{1}$ Rădăuti core and the Dorneşti exposure are assigned to the Lespezi Formation (Ionesi, 2006), being mostly composed of partly compacted and/or laminated ashy-grey clays with some thin intercalations of sand, sandstone and coal. An Early Sarmatian age was postulated for these deposits by lonesi and lonesi (1968) based on macrofossils including Inaequicostata inopinata (Grischevich) and Obsoletiforma lithopodolica (Dubois), as well as microfossil associations with the foraminifers Cycloforina karreri ovata (Serova), Cycloforina karreri karreri (Venglinski), Elphidiella serena (Venglinski) and Elphidium reginum (d'Orbigny). The Lower Sarmatian has been additionally indicated by further foraminiferal (Ionesi, 1968; Ionesi and Guevara, 1993; Dumitriu et al., 2017) as well as calcareous nannofossil (Dumitriu et al., 
2017) studies. The latter authors assigned this succession to the NN7 nannofossil zone (Early Sarmatian).

The Bilca 1 core deposits are composed of clays and sandstones. The lower part of the section belongs to the upper anhydritic unit (Ionesi, 1994) and has been assigned to the Upper Badenian mainly based on a fauna with Spirialis spp. and Davidaschvilia intermedia (Andrusov) (Brânzilă et al., 2005). The upper part of the Bilca 1 core belongs to the Lespezi Formation and has been dated as Lower Sarmatian s.l., based on the occurrence of Inequicostata cf. inopinata (Grishkevich) and Mohrensternia cf. angulata (Eichwald) (Brânzilă et al., 2005) which are considered as marker fossils for the Lower Sarmatian (lonesi, 1991).

The strata studied at the Ripiceni and Costeşti exposures belong to two distinct lithostratigraphic units known as the "Darabani-Mitoc Clays" (Ionesi and lonesi, 1981) and the "Stânca Limestone" (Simionescu, 1902). They are mostly represented by ash-grey clays (partially compacted or laminated) with some thin intercalations of sand, sandstone and limestone. The Ripiceni depositis were initially assigned to the Sarmatian by Simionescu (1903) based on the macrofaunal association with Ervilia podolica Eichwald, Mohrensternia angulata (Eichwald), M. inflata Hörnes and Abra reflexa (Eichwald), and later by the palaeontological studies of Paghida-Trelea (1969), Ionesi and Ionesi (1981, 1982), Brânzilă (1999), and Dumitriu et al. (2017).

\section{MATERIALS AND METHODS}

For this study 172 samples were analysed micropalaeontologically: 34 samples from the Machów sulphur mine (Poland), 18 from the Jamnica M-83 core (Poland), 29 from the $\mathrm{FH}_{3} \mathrm{P}_{1}$ Rădăuți core (Romania), 30 samples from the Bilca 1 core (Romania), 26 from the Dorneşti exposure (Romania), 14 samples from Ripiceni exposure (Romania) and 21 samples from the Costeşti exposure (Republic of Moldova). The separation of microfossils from sediment samples ( $200 \mathrm{~g}$ weight each sample) followed standard washing methods including crushing, washing through a $63 \mu \mathrm{m}$ sieve and drying.

Depending on foraminiferal abundances in different samples, all foraminifera (plankic and benthic) up to 300 specimens were picked. The relative abundance of planktonic foraminifera within the foraminiferal assemblages (P/B ratio), as well as the relative abundance of epifaunal (\%E) and infaunal (\%l) species, and the relative abundance of the most common genera, were calculated (Figs. 2-8). To assess species diversity, the Fisher alpha index was calculated for each section, togheter with the total number of specimens for each sample (Appendixes $1-7^{*}$ ). The environmental requirements of the foraminifera and ostracoda genera recorded in the sections studied are shown in Appendixes 8 and 9, and a new dataset of foraminiferal and ostracoda assemblages of the sections studied was generated.

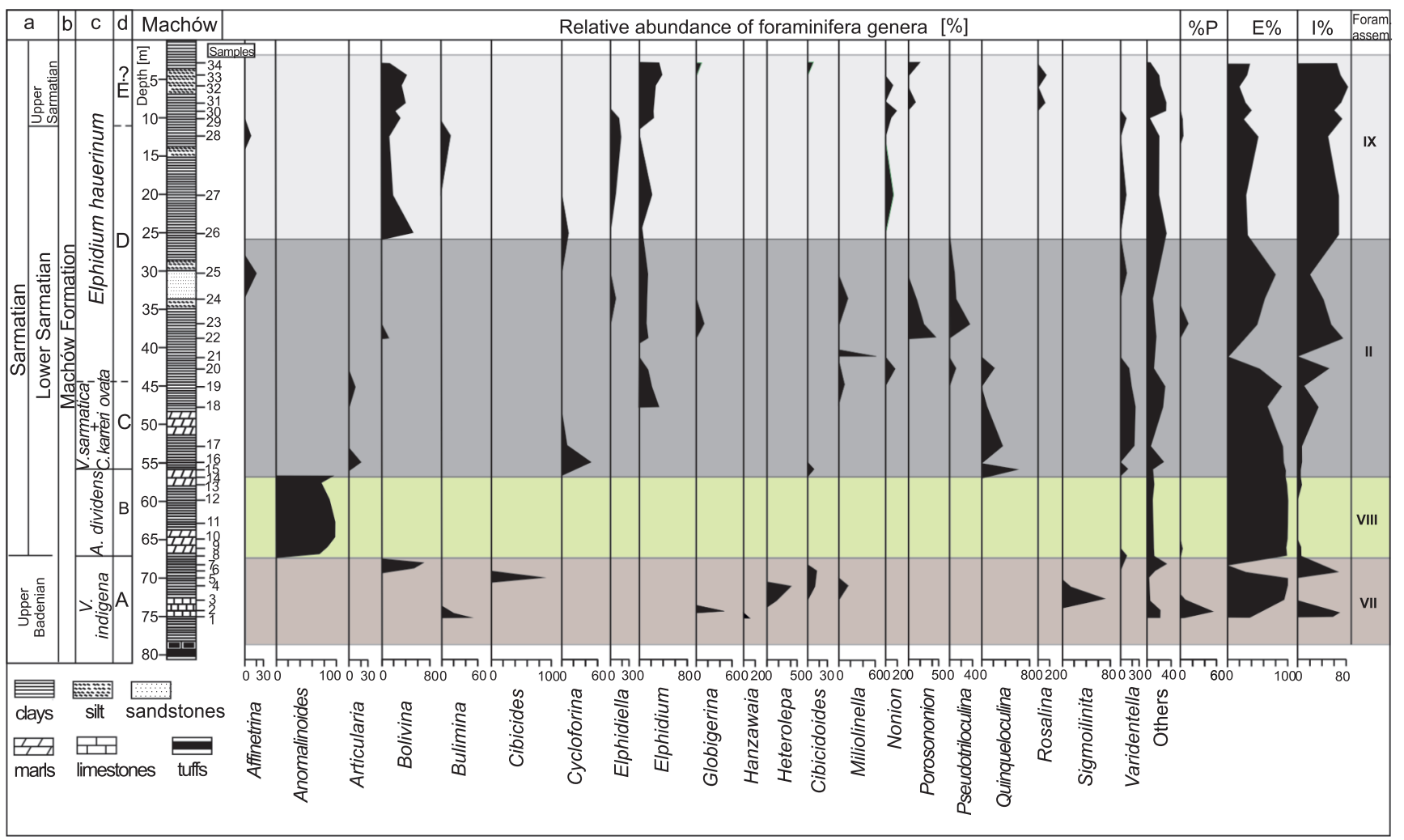

Fig. 2. The relative abundance of the most common foraminiferal genera, $\mathrm{P} / \mathrm{B}$ ratio, epifaunal/infaunal ratio and foraminiferal assemblages in the Machów section

a - chronostratigraphy; b - lithostratigraphy; c - biostratigraphy after Łuczkowska (1964);

$\mathrm{d}$ - biostratigraphy after Dumitriu et al. (2017). ${ }^{*}$ - colours follow the foraminiferal assemblages identified in the sections studied

\footnotetext{
* Supplementary data associated with this article can be found, in the online version, at doi: 10.7306/gq.1568
} 
The present study also took into consideration previously published papers on other Central Paratethys basins [the Vienna and Pannonian (Hungary, Croatia) basins] and the Mediterranean realm (for details and references see Appendixes 10-12). Several samples (no. 440 from the Dorneşti exposure, 470, 482, 488 from the $\mathrm{FH}_{3} \mathrm{P}_{1}$ Rădăuti core and 491/4, 495/D from the Costeşti exposure) were analysed for calcareous nannofossils. For semiquantitative analysis, 200 specimens were counted in longitudinal transverses, randomly distributed. The material investigated from Romania $\left(\mathrm{FH}_{3} \mathrm{P}_{1}\right.$ Rădăuți core, Bilca 1 core, Dorneşti and Ripiceni exposures) and the Republic of Moldova (Costeşti exposure) is deposited in the Original Paleontological Collections Museum of the "Alexandru loan Cuza" University of laşi, Romania. The material from Poland (Machów sulphur mine and Jamnica M-83 core) is curated at the Polish Geological Institute - National Research Institute, Warsaw, Poland.

\section{RESULTS}

In all seven sections, we identified 127 species of calcareous and agglutinated benthic foraminifera, 16 species of planktonic foraminifera, 46 species of ostracod and 16 species of calcareous nannofossil (Appendixes 1-7). In general, microfossils are abundant and very well preserved except in the uppermost part of Bilca 1 core, where the specimens are of low diversity (Fisher alpha index is from 0.43 to 10.71), small and strongly abraded.

The most abundant benthic taxa comprise miliolids (Affinetrina, Articularia, Articulina, Cycloforina, Miliolinella, Pseudotriloculina, Quinqueloculina, Sigmoilinita, Triloculina, Varidentella), elphidiids (Elphidium, Cribroelphidium, Porosononion), nonioniids, bolivinids, buliminids, uvigerinids and lagenids (Favulina and Fissurina). Planktonic foraminifera are represented by Globigerina, Trilobatus, Globigerinita, Globorotalia, Orbulina and Velapertina. Among the agglutinated taxa, Nothia, Haplophragmoides, Reticulophragmium and Textularia species have been recorded. Futhermore, the values of the Fisher alpha index suggest higher species diversity in the Polish Carpathian Foredeep Basin (PCFB) sections studied than in the Eastern Carpathians Foreland Basin (ECFB) (for details see Appendixes 1-7).

In total, integrating our data with the published literature, 24 Badenian planktonic foraminiferal species have been identified in the PCFB and ECFB of which 11 species are common $(\sim 45 \%)$ to both regions (Appendix 10) while $19(\sim 80 \%)$ and nine species $(\sim 38 \%)$ are common to the area studied (both PCFB and ECFB) and the Vienna Basin and Pannonian Basin, respectively (see Appendix 10).

In the case of Badenian benthic foraminifera, we compared the micropalaeontological assemblages of the PCFB and ECFB. Of 81 species of benthic foraminifera identified in the PCFB 51 species, meaning $62 \%$, are common with those of the ECFB (Appendix 10). Correlating benthic foraminifera from the areas studied with those from the Vienna Basin and Pannonian Basin, 47 (57\%) and 38 (46\%) species respectively are in common (Appendix 10). In the Lower Sarmatian deposits, in total eight planktonic foraminiferal species have been recorded in the PCFB and 25 species in the ECFB, of which five species $(\sim 63 \%)$ are common to these regions (Appendix 10). Benthic foraminifera are represented by 80 species in the PCFB and 83 species in the ECFB; 67 species $(\sim 80 \%)$ are common to both regions (Appendix 10). Among the benthic species, 47 and 32 species (constituting $~ 59 \%$ and respectively $40 \%$ ) are in common with the Vienna Basin and the Pannonian Basin (Appendix 10).

\section{FORAMINIFERAL ASSEMBLAGES}

Qualitative and quantitative studies of the foraminiferal associations recorded in the sections studied have identified twelve different foraminiferal assemblages labelled from I to XII. One assemblage (Assemblage VII) has been described from the Badenian deposits and eleven from the Sarmatian. These assemblages are based on specific characteristics including the occurrence of specific taxa, the clear dominance of one or a few characteristic taxa, or the specific taxonomic composition of the assemblage (for detailed description of the foraminiferal assemblages see Appendix 13).

In the samples analysed, ostracods are generally well-preserved; 53 species have been indentified of which 10 are left in open nomenclature. The most abundant species belong to the genera Callistocythere, Aurila, Cytheris and Loxoconcha.

\section{MICROFOSSIL CHARACTERISTICS OF THE SECTIONS STUDIED}

\section{MACHÓW}

In the lowermost part of the section (the depth interval 67-75 m; Upper Badenian) the foraminiferal assemblages are highly diverse (Fisher alpha index is 0.80 to 6.33 ) and composed of benthic epifaunal as well as infaunal morphogroups accompanied by planktonic forms. The epifaunal morphotypes (see e.g., Corliss and Chen, 1988; Rathburn and Corliss, 1994) are represented by Cibicides, Heterolepa, Cibicidoides, Miliolinella and Sigmoilinita, and the infaunal by Bolivina and Bulimina which are the most common in sample 1 ( $75 \mathrm{~m}$ depth) and sample 7 (68 $\mathrm{m}$ depth) representing $60 \%$ of the benthic foraminiferal assemblages. The planktonic genus Globigerina is very abundant in sample 2 (73 $\mathrm{m}$ depth) composing $\sim 50 \%$. Ostracods are relatively rare, only a few specimens of Henryhowella asperrima have been identified. In the uppermost part of the Badenian succession three more ostracod species, Callistocythere incostata, C. sp. and Aurila sp. were encountered. In the upper interval representing the lowermost Sarmatian (67-56.5 $\mathrm{m}$ depth) planktonic forms are absent. The foraminiferal assemblages here are composed almost entirely of the epifaunal species Anomalinoides dividens which comprises $90 \%$. Minor components of these assemblages are Cibicidoides, Quinqueloculina and Varidentella. From $67 \mathrm{~m}$ depth upwards, the ostracod assemblage becomes more diverse. The most frequent species are Cytherois sarmatica, Callistocythere canaliculata, C. incostata, Aurila mehesi, Polycope orbicularis as well as some representatives of Leptocythere. These ostracod taxa remain abundant until $45 \mathrm{~m}$ core depth.

Continuing the section upwards, in the interval $45-56 \mathrm{~m}$ in depth (samples 15-19), the genus Anomalinoides totally disappears. The most abundant forms are infaunal non-keeled elphidiids (Porosononion subgranosus, Elphidiella serena, Elphidium hauerinum), epifaunal miliolids (Cycloforina, Miliolinella, Pseudotriloculina, Quinqueloculina and Varidentella) and 


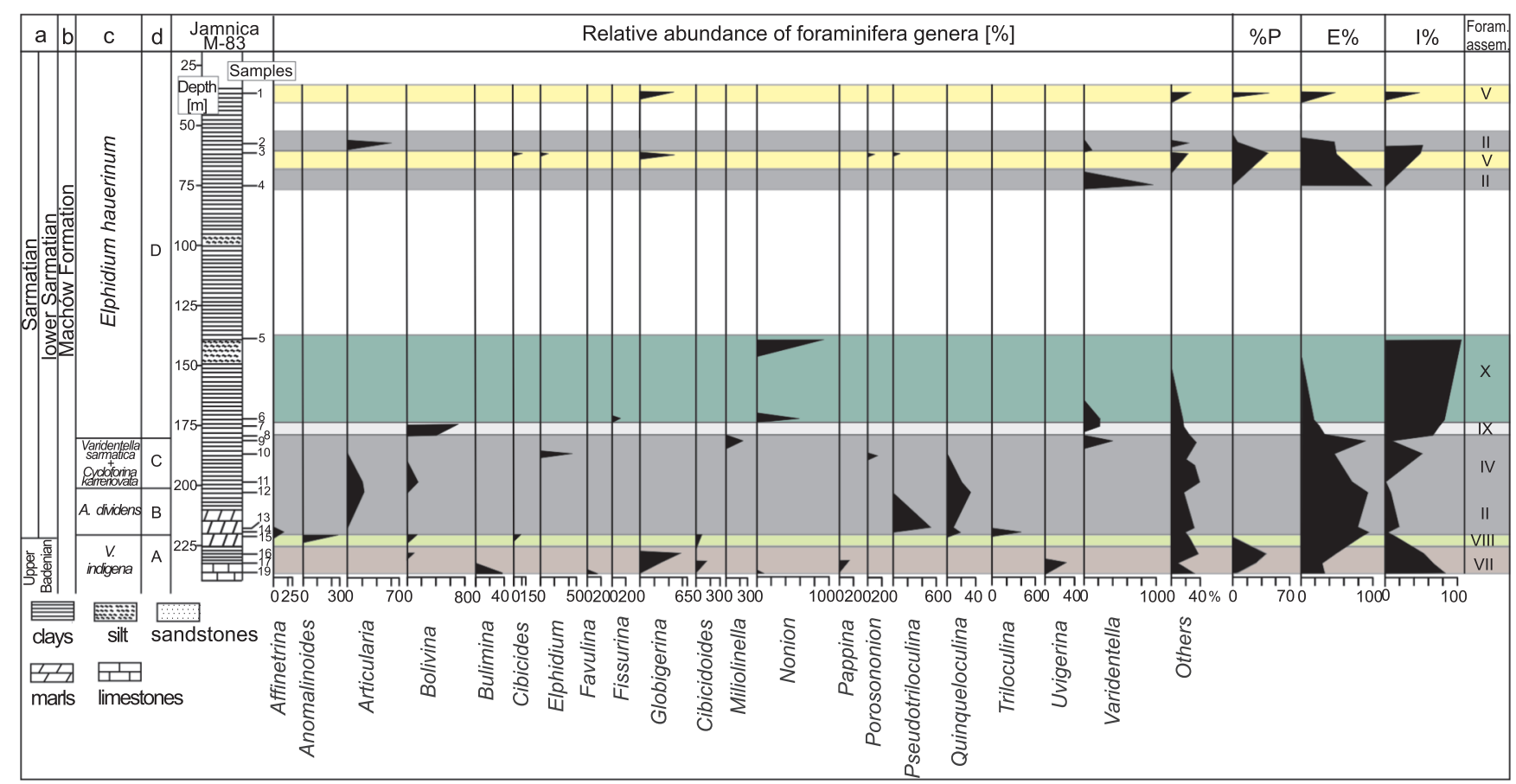

Fig. 3. The relative abundance of the most common foraminiferal genera, $P / B$ ratio, epifaunal/infaunal ratio and foraminiferal assemblages in the Jamnica M-83 core

a - chronostratigraphy; b - lithostratigraphy; c - biostratigraphy after Łuczkowska (1964); d - biostratigraphy after Dumitriu et al. (2017); for other explanations see Figure 2

keeled elphidiids (Elphidium aculeatum, E. joukovi, E. macellum). In the depth interval 30-43 m (samples 20-25), the foraminiferal associations are equally composed of epifaunal (miliolids and keeled elphidiids) and infaunal morphogroups (lagenids and non-keeled elphidiids). Some planktonic forms (Globigerina) were also encountered in sample 23. In the upper interval (samples 26-34) at 2-25 m in depth, the most abundant species belong mostly to the infaunal genera Elphidiella, Bolivina, Bulimina, Nonion, Porosononion and non-keeled Elphidium, which together constitute $70 \%$ of the assemblage. Epifaunal keeled Elphidium, Cycloforina, Neoeponides, Rosalina, Varidentella are also quite common (30\%) (Fig. 2). From $45 \mathrm{~m}$ upwards, in the Machów section, only scarce Xestoleberis dispar represents the ostracod fauna.

\section{JAMNICA M-83}

In the Jamnica M-83 core succession, the lowermost interval, the Upper Badenian (225-235 m in depth, samples 19, 17, 16 ), is characterized by abundant planktonic species especially belonging to the genus Globigerina (sample 16). Among the benthic forms $43 \%$ are represented by infaunal Bolivina, Bulimina, Favulina, Pappina, Nonion, Textularia and Uvigerina while $57 \%$ are represented by epifaunal taxa such as Heterolepa, Cibicidoides and Cibicides. Sample 16 yielded many (50 specimens) agglutinated forms belonging to the following genera: Nothia, Rhizammina, Reticulophragmium, Reophax, Haplophragmoides, Cyclamina, Budashevaella. The next interval, the lowermost Sarmatian (202-220 m depth, samples $15-10)$ is characterized mainly by epifaunal species of the gen- era Anomalinoides, Articularia, Miliolinella, Neoeponides, Pseudotriloculina, Quiqueloculina, Triloculina and Varidentella. Upwards in the section (132-202 m depth) the foraminiferal assemblage is clearly dominated by infaunal Bolivina, Fissurina and Nonion, which together comprise $\sim 90 \%$ of the benthic assemblages. Minor components of this association are $\mathrm{NeO}-$ eponides and Varidentella. The interval between $35-75 \mathrm{~m}$ in depth is dominated by epifaunal forms such as Articulina, Cibicides, Pseudotriloculina, and Varidentella while infaunal non-keeled elphidiids occur in much lower numbers. Representatives of planktonic foraminifer Globigerina appear again in this part of the section, comprising 50\% in samples 1 and 3 (Fig. 3).

In the Jamnica M-83 borehole, 20 ostracod species were recorded (Appendix 2). In the lowermost part of the succession (samples 16, 19), the typical Badenian ostracod taxa Cnestocythere truncata, Henryhowella asperrima, Cytheropteron vespertilio, Loxocorniculum hastatum, Xestoleberis tumida were found. Upwards in the section (175-220 m depth), ostracods are mostly represented by Cytherois sarmatica, Phlyctocythere pellucida, Callistocythere incostata and Aurila mehesi while in the interval $50-75$ m only Callistocythere postvallata and Xestoleberis tumida were identified.

BILCA 1

Planktonic foraminifera mostly dominate the lower part of the section (704-806 m depth, samples 1-4): Globigerina praebulloides, G. bulloides, Trilobatus bisphericus, T. trilobus and Velapertina indigena. Other components of the association are Bulimina, Hansenisca, Heterolepa, Sphaeroidina, Textularia and 


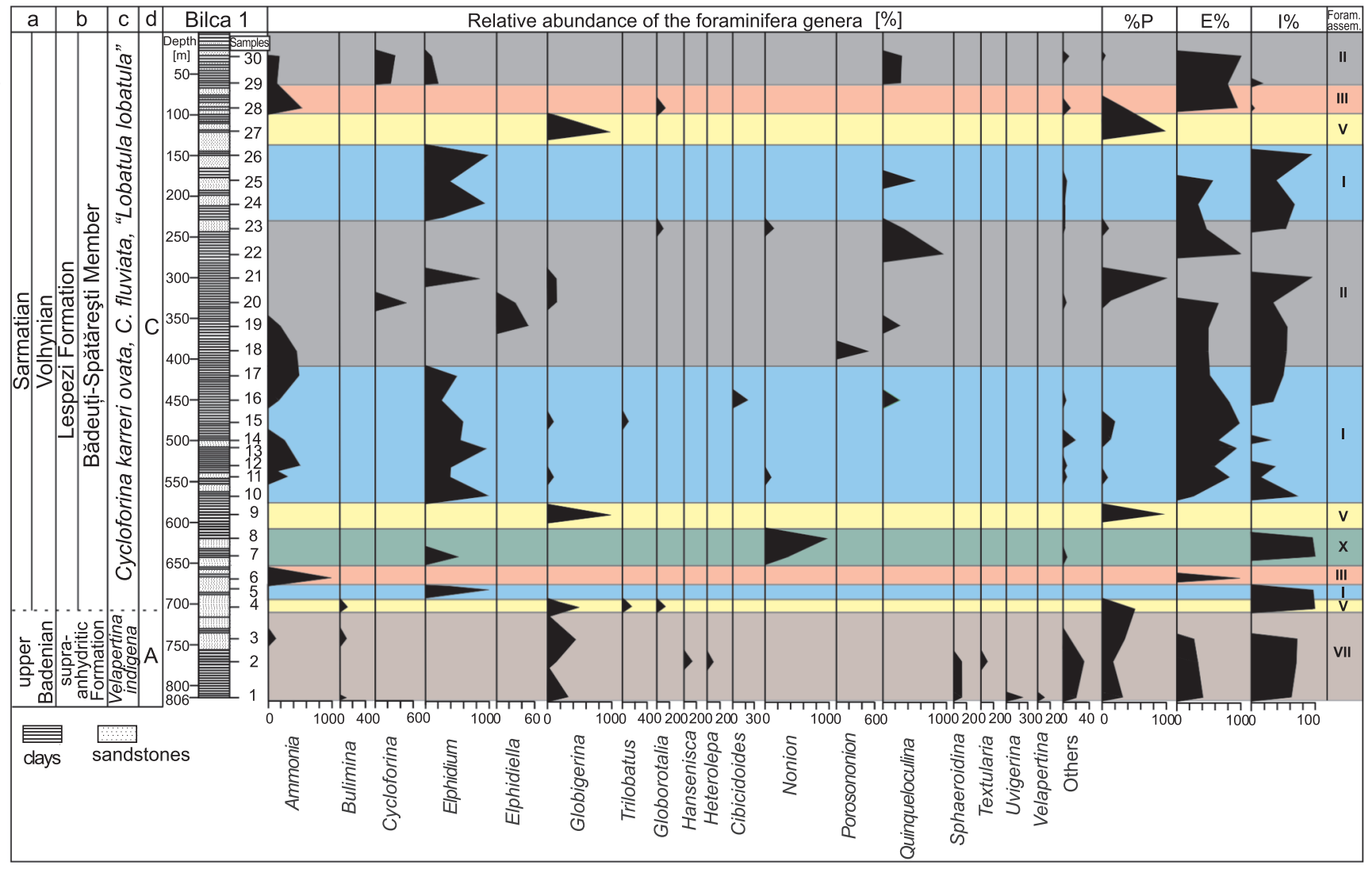

Fig. 4. The relative abundance of the most common foraminiferal genera, $P / B$ ratio, epifaunal/infaunal ratio and foraminiferal assemblages in the Bilca 1 core

a - chronostratigraphy; b - lithostratigraphy; c - biostratigraphy after lonesi (1991); d - biostratigraphy after Dumitriu et al. (2017); for other explanations see Figure 2

Uvigerina, though samples $9(950 \mathrm{~m})$ and $27(120 \mathrm{~m})$ are entirely composed of Globigerina sp. Globorotalia sp. appears in samples $4(704 \mathrm{~m}), 23(240 \mathrm{~m})$ and $28(90 \mathrm{~m})$ (Fig. 4). The upper interval (360-704 m depth) is composed of both epifaunal (Ammonia, keeled Elphidium and Cibicidoides) and infaunal morphogroups (non-keeled Elphidium, Nonion and Porosononion). Upwards in the section, the $30-360 \mathrm{~m}$ interval is mostly dominated by Ammonia, keeled and non-keeled Elphidium, Cycloforina and Quinqueloculina. Planktonic foraminifera were also recorded in these intervals. Only one ostracod species, Cytheridea acuminata, was recorded in the section.

\section{$\mathrm{FH}_{3} \mathrm{P}_{1} \mathrm{RĂDĂUTTI}$}

In the lower part of the section (239 and 174 m depth, samples 467 and 473 respectively), the foraminiferal assemblages are entirely composed of planktonic foraminifera (Globigerina and Globorotalia). Upwards in the succession (175-200 m depth, samples $472,481,471,470,474)$, the foraminiferal associations are characterized mostly by benthic epifaunal morphotypes: e.g., Ammonia, Cycloforina, keeled Elphidium, Cibicidoides, Miliolina, Pseudotriloculina. The next interval (90-175 m) has yielded calcareous epifaunal genera such as Ammonia which represents $100 \%$ of the foraminiferal assemblage in sample 485 and $97 \%$ in sample 484, Cycloforina (100\% in sample 476$)$, keeled Elphidium (60\% in sample 475 ) and Pseudotriloculina (60\% in sample 479). Minor components of this interval are the genera Articularia, Elphidiella, Nodo- baculariella, Nonion, Porosononion and Varidentella. Planktonic species of Globigerina occur in samples 477 (40\% of the assemblage) and 483 (50\% of the assemblage). The upper part of the succession (27-90 m depth) is mainly characterized by Cycloforina and keeled Elphidium. Ammonia, Articularia, Elphidiella and Nonion species also occur in this interval. Globigerina represents $25 \%$ of the assemblage in sample 487 (Fig. 5).

In total, 25 ostracod species were found in the $\mathrm{FH}_{3} \mathrm{P}_{1}$ Rădăuţi borehole material. In the lower part of the section two samples 470, 474 (170-180 m depth) include a significant number of ostracod species. Although ostracod abundance is low, dominant species were distinguished as Cytheridea hungarica, Aurila mehesi, Callistocythere canaliculata, C. egregia, C. incostata and Euxinocythere praebosqueti, accompanied by Loxocorniculum schmidi, Senesia vadaszi and Xestoleberis fuscata. The ostracods are relatively scarce in the upper part of the section (25-155 m). The most representative species are Loxoconcha minima, L. impressa, Hemicyprideis dacica dacica and Callistocythere spp.

The nannofossil content identified in samples from this section consists of long-ranging species such as Reticulofenestra pseudoumbilicus, R. minuta, R. minutula, Coccolithus pelagicus, Co. miopelagicus, Helicosphaera carteri, Pontosphaera japonica, Sphenolithus abies and Calcidiscus leptoporus. Reticulofenestra taxa represent $\sim 25 \%$ of the total assemblage, while Discoaster and Sphenolithus species comprise 20\%. The rest of the in situ assemblage is composed of Helicosphaera, Calcidicus, Pontosphaera and Coccolithus. 


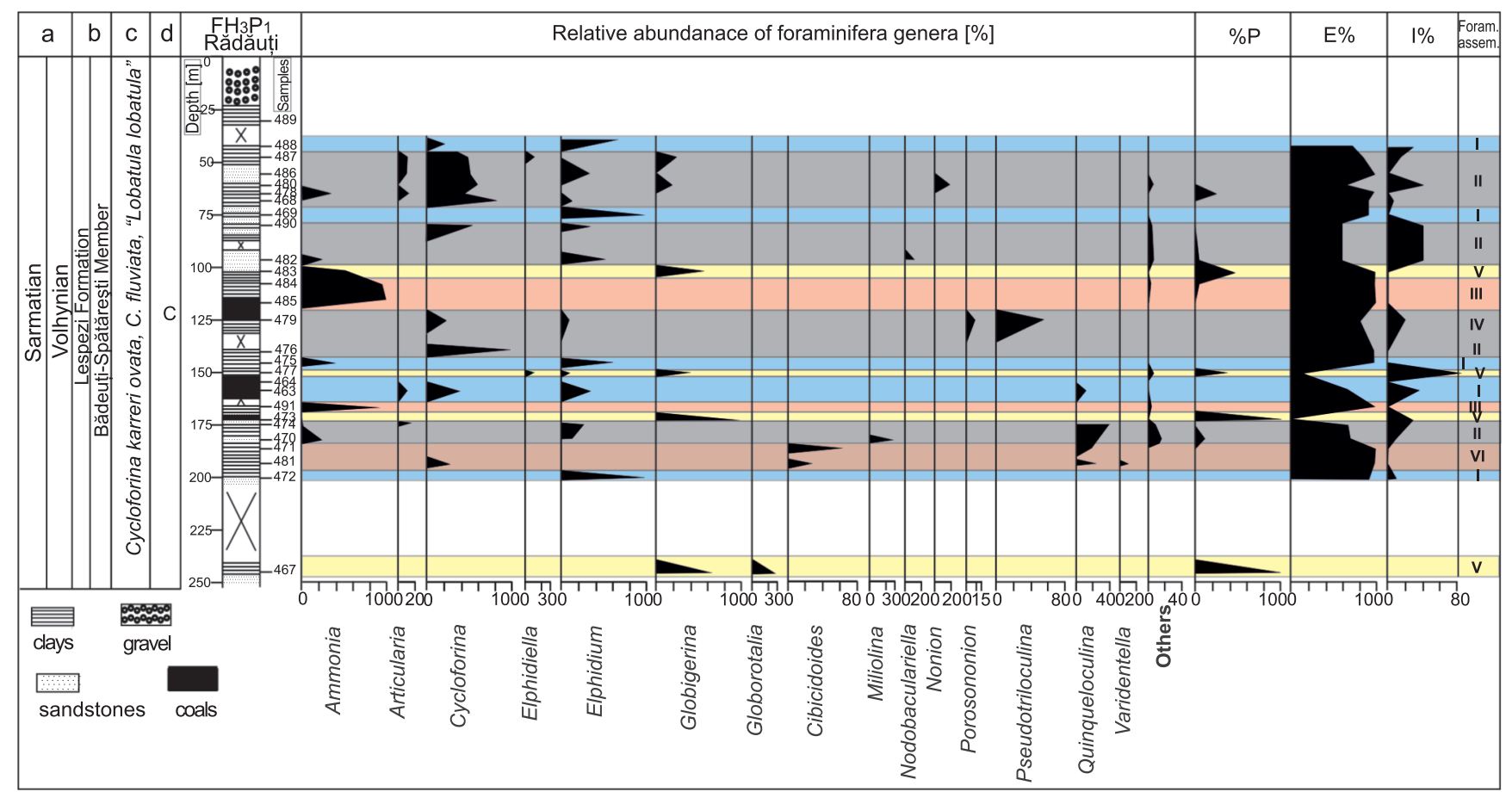

Fig. 5. The relative abundance of the most common foraminiferal genera, $P / B$ ratio, epifaunal/infaunal ratio and foraminiferal assemblages in the $\mathrm{FH}_{3} \mathrm{P}_{1}$ Rădăuţi core

a - chronostratigraphy; b - lithostratigraphy; c - biostratigraphy after lonesi, (1991); d - biostratigraphy after Dumitriu et al. (2017); for other explanations see Figure 2

DORNEŞTI

Foraminiferal assemblages of the Dorneşti locality are composed of epifaunal (Ammonia, Articularia, Cycloforina, keeled Elphidium and Quinqueloculina) as well as infaunal representatives (Bolivina, Bulimina, Elphidiella, non-keeled Elphidium and Nonion). Planktonic forms of Globigerina occur in samples $101-103,108,110$ and 165 and constitute $10-78 \%$ of all foraminifera (Fig. 6). Ostracods are scarce and were found only in two samples (samples 440 and 146), and are represented by six species, the most abundant being Cytheridea hungarica and Euxinocythere praebosqueti.

The calcareous nannofossils identified in the lower part of the section contain diverse assemblages with discoasterid taxa, i.e., Discoaster kugleri and $D$. deflandrei which along with Sphenolithus abies represent $\sim 35 \%$ of the total assemblage. The rest of the in situ taxa are represented by reticulofenestrids and species of Helicosphaera, Calcidiscus, Pontosphaera and Coccolithus.

\section{RIPICENI}

35 species of calcareous benthic foraminifera were identified in the Ripiceni exposure. Agglutinated and planktonic foraminifera are absent. Excepting samples a and g, all the samples yielded foraminiferal assemblages entirely composed of epifaunal morphotypes. Ammonia, Cycloforina, Cibicides, Cibicidoides and Quinqueloculina are the most abundant genera in the lower part of the section (samples a-c, e-g) while spinose elphidiids (Elphidium aculeatum and E. reginum) and Quinqueloculina are common in the upper part of the section (samples i, k, m; Fig. 7). The most numerous ostracod taxa are Cytherois sarmatica, Cytheridea hungarica, Aurila mehesi and Callistocythere canaliculata alongside C. maculata, C. incostata, Aurila merita, Phlyctocythere pellucida, Loxoconcha, and Xestoleberis species.

\section{COSTEŞTI}

The foraminiferal assemblage of the Costeşti section is clearly dominated by benthic epifaunal morphotypes belonging to Articularia, Articulina, Cycloforina, Pseudotriloculina and Quinqueloculina in its lower part, and by infaunal forms (Fissurina and Porosononion) in the upper part (Fig. 8). Planktonic foraminifera are absent. The ostracod fauna is rather scarce and only found in three samples (495/D, 491/1 and 491/5); the most common species are Loxocorniculum schmidi and Lo. hastatum. The calcareous nannofossil content identified in this section comprised only one barren sample (495/D) and another one (sample 491/4) containing only reworked taxa from older Cretaceous and Paleogene deposits.

\section{DISCUSSION}

PALAEOENVIRONMENTAL CHANGES ACROSS THE BADENIAN-SARMATIAN EXTINCTION EVENT

The Badenian/Sarmatian boundary is commonly associated with the regional Badenian-Sarmatian Extinction Event (BSEE) (Harzhauser and Piller, 2007) interpreted as a cata- 


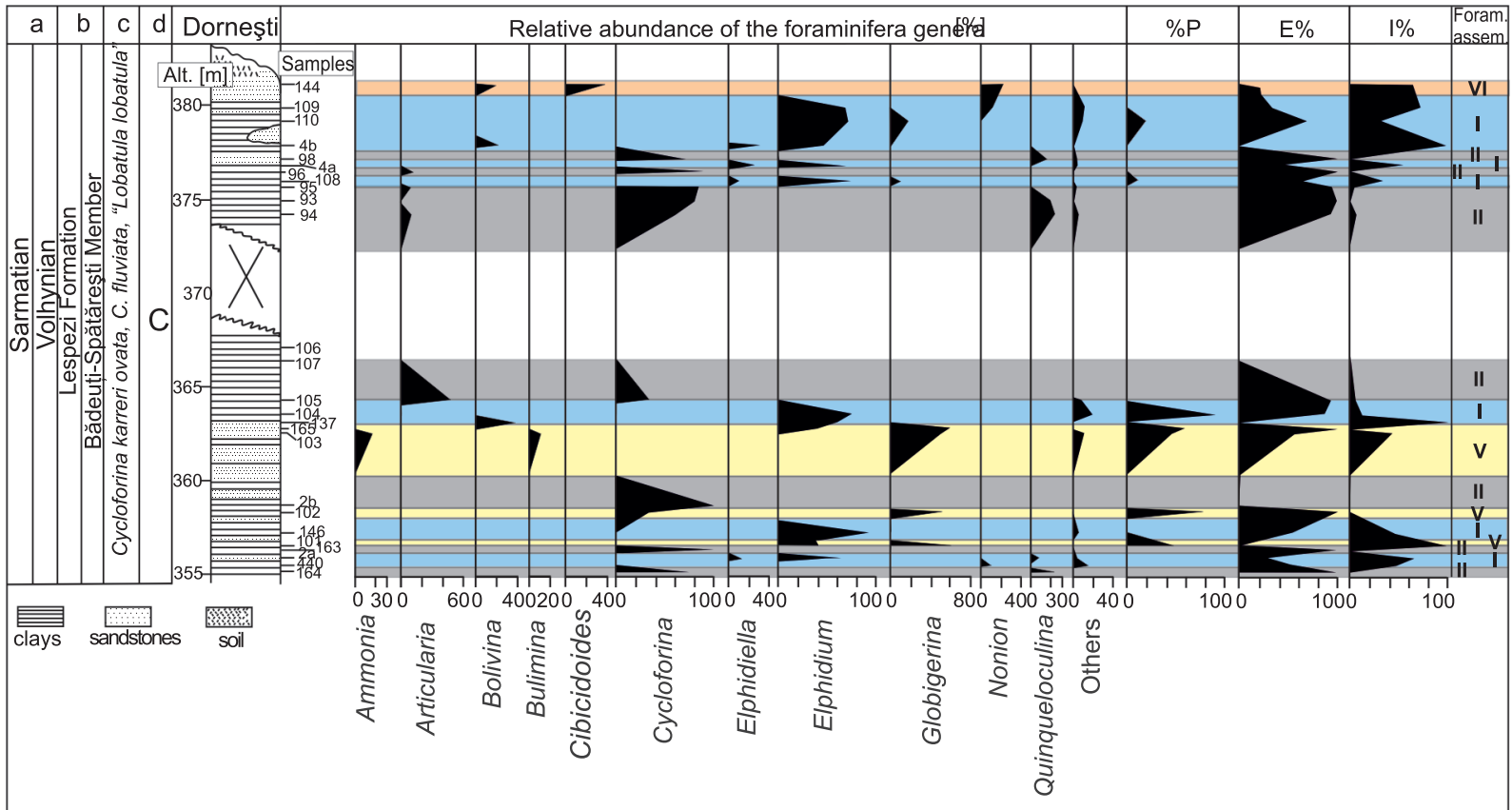

Fig. 6. The relative abundance of the most common foraminiferal genera, $\mathrm{P} / \mathrm{B}$ ratio, epifaunal/infaunal ratio and foraminiferal assemblages in the Dorneşti section

a - chronostratigraphy; b - lithostratigraphy; c - biostratigraphy after lonesi (1991);

d - biostratigraphy after Dumitriu et al. (2017); for other explanations see Figure 2

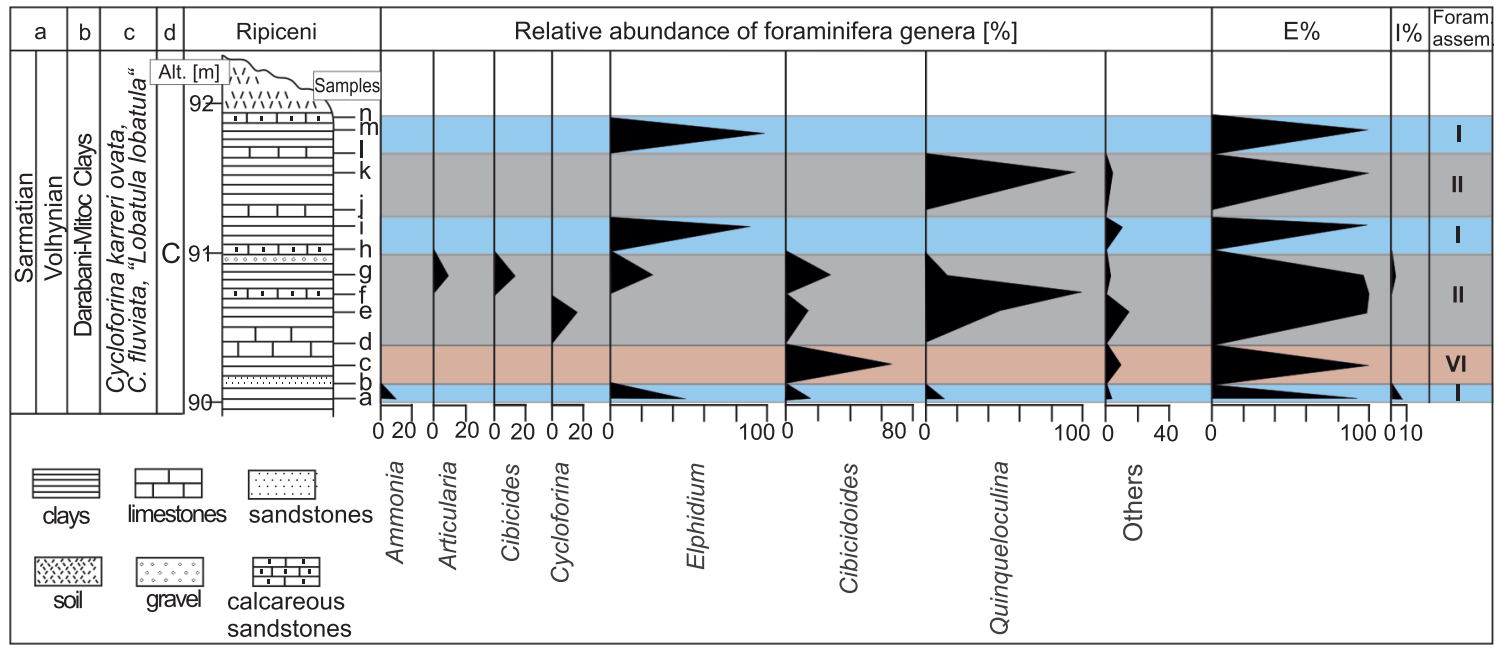

Fig. 7. The relative abundance of the most common foraminiferal genera, P/B ratio, epifaunal/infaunal ratio and foraminiferal assemblages in the Ripiceni section 


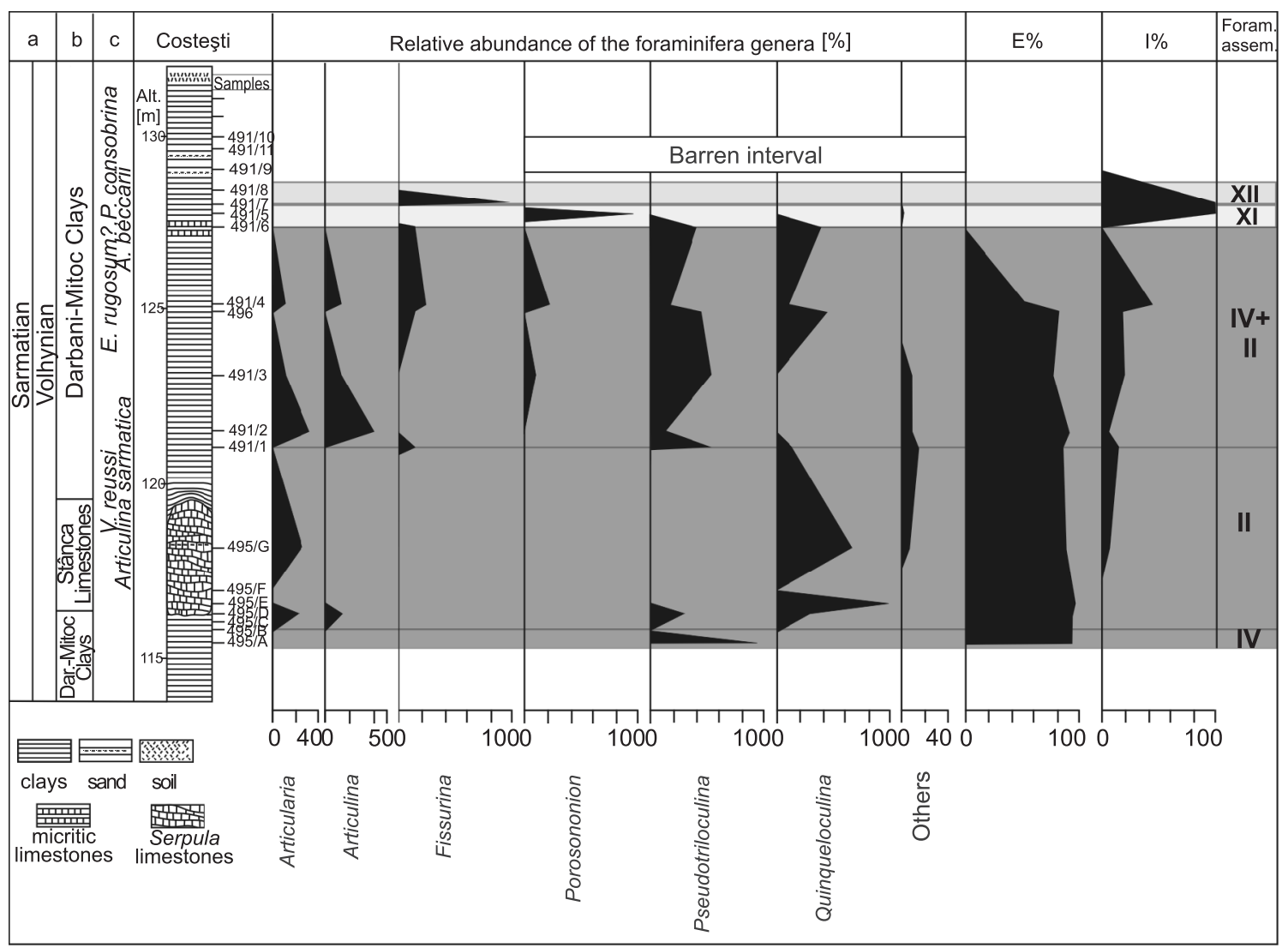

Fig. 8. The relative abundance of the most common foraminiferal genera, P/B ratio, epifaunal/infaunal ratio and foraminiferal assemblages in the Costeşti section

a - chronostratigraphy; b - lithostratigraphy; c - biostratigraphy after lonesi (1991);
d - biostratigraphy after Dumitriu et al. (2017); for other explanations see Figure 2

strophic event in the Central Paratethys, marked by the extinction of the majority of Badenian gastropod, foraminifer and ostracod taxa (Harzhauser and Piller, 2004, 2007; Tóth et al., 2010; Palcu et al., 2015). Following this general faunal impoverishment, the material studied shows the disappearance of common Badenian taxa, including planktonic foraminifera (e.g., Velapertina indigena, Globigerina concinna, G. diplostoma, G. falconensis, G. globularis, G. regularis, Globigerinoides quadrilobatus, GI. transitoria, Trilobatus trilobus, Globoquadrina langhiana), calcareous benthic (e.g., Heterolepa dutemplei, Hansenisca soldanii, Melonis pompilioides, Hanzawaia crassiseptata, Sigmoilinita tenuis, Pullenia bulloides) and agglutinated foraminifera (e.g., Nothia, Haplophragmoides, Textularia, Reticulophragmium) (Assemblage VII) as well as ostracods (e.g., Cytheropteron vespertilio, Eocytheropteron inflatum, Semicytherura filicata, Verucocythereis sp., Kirthe sp.). During the BSEE interval, discernible foraminiferal assemblage changes within both benthic and planktonic associations are recorded. Given that planktonic foraminifera need generally fully marine conditions with a minimum depth of some tens of metres (Bé, 1977; Hemleben et al., 1989; Schiebel and Hemleben, 2005, 2017), the occurrence of moderately diverse planktonic foraminifera (Globigerina, Globigerinita, Globorotalia, Trilobatus, Orbulina, Velapertina) in the uppermost Badenian deposits of the PCFB (Machów, samples 1 and 2 and Jamnica M-83, samples 16, 17 and 19) as well as in the ECFB (Bilca 1, samples 1-4) and their rarity in the lowermost Sarma- tian (e.g., Globigerina bulloides, G. praebulloides, Globorotalia miocenica) indicate the existence of almost fully marine conditions during the latest Badenian followed by a significant regression and possibly much more restricted-marine conditions above the Badenian-Sarmatian boundary. This is consistent with the idea of a significant transgression and occurrence of fully marine environments across the whole Central Paratethys during the latest Badenian (Kováč et al., 2007; Filipescu and Silye, 2008). These were were quickly replaced by shallower environments with variable salinity during the earliest Sarmatian (Koubová and Hudáčková, 2010; Báldi et al., 2017). This phenomenon is additionally interpreted as associated with a general cooling of climate (Gonera et al., 2000; Bicchi et al., 2003; Báldi, 2006; Kováčová et al., 2009).

The postulated conditions can be additionally supported by our studies of benthic foraminiferal assemblages changes across the boundary. These changes include a significant decrease in low-oxicity and high-nutrient taxa e.g., Uvigerina, Bulimina, Bolivina, which are mainly characteristic of normal and generally open marine environments, and the onset of dominance of Anomalinoides dividens, miliolids and cibicidids (Assemblage VIII), taxa typical of very shallow and marginal marine environments and which tolerate slightly brackish or hypersaline waters (e.g., Łuczkowska, 1974; Thomas, 1990; Murray, 1991, 2006; Gebhardt et al., 2009; Gedl and Peryt, 2011; Lowery et al., 2017; Appendix 8). 
The sea level fall during the Badenian-Sarmatian transition may be additionally supported by a decrease across the boundary of the proportion of planktonic foraminifera within the total foraminiferal assemblages in Machów (from $\sim 60$ to $\sim 2 \%$ ) and Jamnica M-83 (from 56 to $0 \%$ ) sections (Figs. 2 and 3 ). This ratio, however, must be treated with caution since it strongly depends on the salinity as well as on the abundance of benthic foraminifera, which may be related to factors such as oxygenation or food supply. A more reliable method seems to be analysis of the planktonic foraminiferal depth-morphogroup model (Keller, 1985), which is based on modern analogues such the depth stratification of recent species composition (Bé and Hamlin, 1967; Bé, 1977; Schiebel and Hemleben, 2005). According to this model, simple Globigerina-like or Globigerinoides-like morphotypes live near the water surface (up to tens of metres) while more complex, Globorotalia show preferences for deeper/intermediate habitats. Consequently, the common occurrence of these forms in the Late Badenian of the PCFB and their rarity in the Sarmatian (see also Szczechura, 2000; Garecka and Olszewska, 2011; Peryt, 2013) supports the idea of a sea level fall during the Badenian-Sarmatian transition.

Similarly to foraminifera, ostracods also suffered a strong decrease across the BSEE in the sections studied. Of $>100$ Badenian species, only a few survived into the Sarmatian (Tóth et al., 2010). In the material analysed we identified four typical Badenian species which survived into the Sarmatian, Henryhowella asperrima, Loxocorniculum hastatum, Senesia vadaszi, and Xestoleberis fuscata. Badenian species are mostly represented by deeper circa-littoral to epibathyal forms such as Henryhowella asperrima, and Sarmatian species by endemic much shallower forms, such as Callistocythere incostata, Cnestocythere truncata, Euxinocythere praebosqueti, Cytheridea hungarica, Aurila merita, and Aurila mehesi (Tóth et al., 2010). In addition to these endemic Sarmatian forms, many common ostracod taxa still typical of shallower waters (from upper infralittoral to epineritic) have been recorded - Cyamocytheridea, Loxoconcha, Loxocorniculum and Xestoleberis (Hartmann, 1975; ter Borgh et al., 2014). Accordingly, the occurrence of deeper water ostracods in the Badenian deposits and the appearance of shallower water species in the Sarmatian provide additionally evidence of a sea level fall across the B/S boundary.

Benthic foraminiferal assemblages from the uppermost Badenian of Poland and Romania (Bilca 1) include a large number of buliminids, bolivinids, uvigerinids, and representatives of Cibicides, Heterolepa, Hanzawaia, and Cibicidoides, enrolled or partly uncoiled miliolids such as Miliolinella, Pseudotriloculina, and Sigmoilinita as well as agglutinated foraminifera. The large number of epifaunal (cibicidids, anomalinids and miliolids) together with diverse and abundant relatively deep infaunal taxa (buliminids, bolivinids and uvigerinids) indicate a relatively large organic matter supply (see Báldi, 2006; Kováčová et al., 2009; Kováčová and Hudáčková, 2009) and relatively good/moderate oxygenation at the sea floor (mesotrophic conditions) (see Jorissen et al., 1995) with the expected decrease in oxygenation and increase in organic matter deeper in the sediment.

High bottom-water oxygen concentrations are also supported by the presence of large oxygen-consuming cytheracean ostracods (Whatley, 1995) e.g., Callistocythere, Aurila and Cytheridea spp. Fully marine conditions are also indicated by the Badenian calcareous nannoplankton assemblages, which are characterized in the Central Paratethys by high abundance and diversity. Furthermore, in the intra- and extraCarpathian regions of Romania, the biostratigraphy based on nannofossil distribution (Mészáros, 1992; Mărunțeanu, 1999;
Melinte-Dobrinescu and Stoica, 2013) allowed the identification of all biozones established for the Mediterranean realm and the open-ocean Indo-Pacific realm.

\section{FROM FULLY-MARINE TO BRACKISH: FLUCTUATING ENVIRONMENT THROUGH THE SARMATIAN}

The Badenian is often regarded as the last fully marine interval in the Central Paratethys (Papp, 1954, 1956) with connections between the Central and Eastern Paratethys through the Bârlad Straits (Palcu et al., 2017) and between the Paratethys Sea and the Mediterranean realm through the Slovenian Corridor (Bartol et al., 2014) or through the Axios (Vardar) Trench (Studencka et al., 1998). However, Kováč et al. (2017) considered that the Slovenian corridor was probably closed during this time interval. By conrast, the Sarmatian of the Central Paratethys is commonly viewed as more restricted with mostly brackish conditions (Papp, 1954, 1956; Papp et al., 1974). However, some authors (Filipescu et al., 1999, 2014; Piller and Harzhauser, 2005; Corneé et al., 2009) suggest the existence of normal salinity during the Sarmatian.

Consequently, the planktonic foraminifera recorded in some intervals of the Lower Sarmatian of Poland and Romania have been interpreted as reworked from Badenian sediments (Ionesi, 1968; Paghida-Trelea, 1969; Brânzilă, 1999, 2004; Brânzilă and Chira, 2005; Ionesi, 2006; Brânzilă et al., 2011) or haing been introduced (Łuczkowska, 1964; Odrzywolska-Bieńkowa, 1974), probably due to an influx of marine water into the Carpathian Foredeep from the Mediterranean Basin (Szczechura, 2000) or Indo-Pacific region (Filpescu and Silye, 2008; Stoica et al., 2013; Silye, 2015) Planktonic foraminifera recorded (Figs. 3-6) in the Lower Sarmatian deposits (Assemblage V) of the area studied are, however, very well-preserved, abundant, and taxonomically diverse (representatives of Globigerina bulloides, G. praebulloides, Trilobatus trilobus, T. bisphericus and Globorotalia miocenica), indicating rather an in situ occurrence. Accordingly, some short-lived transgressions and some periods of temporary nearly normal marine conditions during the Sarmatian, with possibly slightly higher salinity (Filipescu et al., 1999; Latal et al., 2004; Piller and Harzhauser, 2005) have been postulated. Moreover, in this foraminiferal assemblage (V) planktonic foraminifera co-occur with benthic taxa such as Bolivina and Bulimina, which also suggests slightly deeper conditions with generally normal salinity (Murray, 2006; Tóth et al., 2010; Peryt, 2013). Additionally, the ostracod species of the lowermost part of the Sarmatian deposits of the PCFB sections, such as Henryhowella asperrima, Callistocythere spp., Loxocorniculum hastatum and Xestoleberis tumida support the occurrence of almost fully marine conditions (see ter Borgh et al., 2014). Similarly, in the lowermost part of the $\mathrm{FH}_{3} \mathrm{P}_{1}$ Rădăuţi borehole (ECFB) the occurring ostracod assemblages are characteristic of fully marine waters (ter Borgh et al., 2014).

The moderately common occurrence of planktonic foraminifera (Globigerina), which constitutes up to $90 \%$, in the lower Volhynian (=Lower Sarmatian) of the northwestern part of the Moldavian Platform (the area of the $\mathrm{FH}_{3} \mathrm{P}_{1}$ Rădăuți, Bilca 1 and Dorneşti sections) as well as short-lived appearances of the relatively deeper-dwelling Globorotalia, suggest the occurrence of a deeper basin during the Early Volhynian in this area than in the northeastern part of the ECFB (the area of the Ripiceni and Costeşti sections) where planktonic foraminifera are sporadic. These data follow the general scheme of facies development of the ECFB (Grasu et al., 2002; Miclauş et al., 2011), namely, the deeper foredeep depozone for the $\mathrm{FH}_{3} \mathrm{P}_{1}$ Rădăuți, Bilca 1 cores 
and Dorneşti section and the much shallower backbulge depozone for the Ripiceni and Costeşti sections (Fig. 1B). This foraminiferal data also indicates that during the Early Sarmatian, this area was possibly slightly deeper than the area of the Machów and Jamnica M-83 sections, where planktonic foraminifera are significantly less frequent.

Following the scheme of planktonic foraminiferal morphogroups (e.g., Leckie, 1987), the occurrence of relatively shallow-dwelling forms (Globigerina), and the sporadic occurrence of deeper-dwelling foraminifera with a pseudokeel or acute periphery, indicates that the general water depth of the foredeep depozone area during the Early Volhynian is estimated to be up to a few tens of metres but much $<100 \mathrm{~m}$. This assumption is supported by the presence in the same interval of benthic foraminifera (see Figs. 2-6) and by the ostracod fauna (Callistocythere, Cytheridea, Aurila and Xestoleberis), which have been described as characteristic of the upper infralittoral environment (Breman, 1975) and the epi-neritic facies (Liebau, 1975). Additionally, Callistocythere flavidofusca (Ruggieri, 1950), which is similar to Ca. canaliculata, does not exceed 100 $\mathrm{m}$ water depth, being very abundant near $70 \mathrm{~m}$ (Bonaduce et al., 1976). The occurrence of Hemicyprideis dacica dacica, the counterpart of a Cyprideis species, in the upper part of the $\mathrm{FH}_{3} \mathrm{P}_{1}$ Rădăuţi section, may indicate highly fluctuating salinities in the basin.

Interestingly, the relatively deeper-dwelling foraminifer Globorotalia of the Upper Badenian strata from the areas studied of the ECFB is represented by a single species i.e., Globorotalia mayeri. By contrast, the Sarmatian globorotaliids are much more taxonomically diverse, represented by Globorotalia mayeri, G. bykovae, G. miocenica, G. cosovensis, G. marginodentata and Globorotalia sp. (for details and references see Appendix 10). This might argue against the hypothesis of a general sea level drop during the Badenian-Sarmatian transition in this part of the ECFB, but alternatively it may indicate a record of stronger subsidence during the Sarmatian than in the Badenian, possibly resulting from movement of the Carpathian front. The depocenter was possibly moving eastwards (lonesi, 1994), resulting in more rapid subsidence and the occurrence of a slightly deeper basin in the NW part of the ECFB during the Early Sarmatian than in the Badenian.

In general, the Sarmatian salinity of the Central Paratethys has been considered as being brackish, transition between the normal marine conditions of the Badenian to the very brackish to fresh conditions of the Pannonian (Báldi et al., 2017). Our studies indicate that during the Early Sarmatian, the part of the Central Paratethys studied was not totally brackish but rather the salinity was variable, oscillating from brackish, through normal marine to slightly elevated, probably due to some minor transgressions when short-lived near-fully marine conditions were re-established both in the PCFB and in the ECFB.

The twelve clearly distinguishable foraminiferal assemblages identified in the Sarmatian deposits studied indicate changing environmental conditions of the parts of the PCFB and ECFB studied, which are as follows. A brackish and shallow environment, up to $50 \mathrm{~m}$ depth (Murray, 2006; PérezAsensio et al., 2012), can be assigned to foraminiferal Assemblage III, which is clearly dominated by the species Ammonia beccarii, and which has been observed only in the eastern part of the Paratethys (the $\mathrm{FH}_{3} \mathrm{P}_{1}$ Rădăuţi and Bilca 1 sections). In general, Ammonia beccarii is commonly regarded as an opportunistic species which can tolerate salinities from 10-30\%o (Murray, 2006), being able to adapt to hyposaline conditions (Murray, 1968). Its predominance or the low diversity association marked by the domination of this species usually indicate shallow and brackish environments (Cimerman and Langer,
1991; Hayward and Hollis, 1994; Filipescu et al., 2014). In the brackish Holocene deposits of the NW Black Sea, as in the coastal regions, where the salinity is $7-8 \%$, Ammonia beccarii is the dominant species, producing monospecific assemblages (Briceag and lon, 2014). Still very shallow but, almost normal marine salinity conditions are associated with Assemblage I, recorded in the Romanian and Moldavian parts studied of the ECFB, which is characterized by the presence of elphidiids [especially the large-keeled Elphidium species (E. reginum and $E$. aculeatum)], characterizing depths from 0-50 m (Murray, 2006; Gedl et al., 2016). Moreover, this assemblage may indicate generally oligotrophic conditions and a rich sea-grass vegetation substrate (Langer, 1993; Tóth and Görög, 2008; Koubová and Hudáčková, 2010; Zilinska et al., 2010; Filipescu et al., 2014). Shallow, euphotic conditions of a normal marine salinity environment (Murray, 2006; Peryt and Jasionowski, 2012) are also correlated with foraminifer Assemblage VI, identified in the $\mathrm{FH}_{3} \mathrm{P}_{1}$ Rădăuţi, Dorneşti and Ripiceni sections. Normal marine salinity but deeper conditions are also supported by the presence of planktonic foraminifera (Assemblage V) (Hemleben et al., 1989) in the Jamnica $\mathrm{M}-83, \mathrm{FH}_{3} \mathrm{P}_{1}$ Rădăuţi, Bilca 1 and Dorneşti sections.

Several intervals with slightly higher salinity have been identified in all the sections studied (Figs. 2-8) and correspond to Assemblages II and IV, dominated by miliolids. This group of foraminifera is peculiar to shallow waters with salinities varying from normal to hypersaline (Łuczkowska, 1974; Murray, 2006; Filipescu et al., 2014) and cannot live in hyposaline conditions (Murray, 1968). Accordingly, the presence of these assemblages in the sections studied indicates episodes of slightly higher salinity during the Early Sarmatian, both in PCFB and in the ECFB, which is against the traditional opinion that the Sarmatian was in general a brackish period in the Paratethys (Papp, 1956; Czepiec and Kotarba, 1998; Fordinál et al., 2006; Ionesi, 2006; Vrsaljko et al., 2006; Maissuradze and Koiava, 2011).

Assemblage $\mathrm{X}$, which is $98 \%$ composed of Nonion species, has been recognized in the Jamnica M-83 and Bilca 1 sections while Assemblage $\mathrm{XI}$, composed $100 \%$ of Porosononion species, occurs in the Costeşti section (Figs. 3-4 and 8). These foraminifera are usually associated with environments of brackish to normal marine salinity conditions (Avnaim-Katav et al., 2013; Filipescu et al., 2014; Silye, 2015) and decreasing salinity (for low species-richness assemblages) (Culver et al., 2012) and possible increasing in nutrient supply. Assemblage IX (Figs. 2 and 3) of the Upper Sarmatian, composed of high abundant infaunal species belonging to Bulimina and Bolivina, indicates deeper sea depths (middle neritic) with generally normal-salinity and low oxygen-content at the sea-floor (Murray, 1991; Sen Gupta and Machain-Castillo, 1993; Jorissen et al., 1995; Kováčová et al., 2009; Dubicka et al., 2014; Drinia et al., 2016; Pezelj et al., 2016). Similar conditions can be postulated for the deposits of the uppermost part of the Costeşti section, represented by Assemblage XI, which is entirely composed of representatives of Fissurina (Silye, 2015).

The taxonomic composition of the Sarmatian ostracod assemblages, especially the occurrence of Aurila, Callistocythere, Henryhowella, Xestoleberis, Loxoconcha, Loxocorniculum in the sections studied also indicates fluctuations in salinity (van Morkhoven, 1963; Szczechura, 2006; Tóth et al., 2010; ter Borgh et al., 2014) both in PCFB and ECFB.

The calcareous nannofossils in the sections studied indicate a fully marine environment, at least for some short periods, since the majority of the species live in waters with salinities higher that 20-22\%o (Tappan, 1980). An exception is the extant species Emiliania huxleyi that may be identified today in waters 
with lower salinity, i.e., $11 \%$ in the Azov Sea and Black Sea (Bukry, 1974; Melinte-Dobrinescu and Ion, 2013). Futhermore, the common presence of discoasterids and sphenoliths in the deposits studied from the lower part of the Sarmatian of ECFB also supports an interpretation of intervals with normal marine conditions, since these nannofossils are mostly confined to open marine settings (Backman and Pestieux, 1987).

Fluctuations of salinity during the Sarmatian have also been documented in other parts of the Central Paratethys (e.g., Filipescu et al., 1999, 2014; Piller and Harzhauser, 2005; Ruman et al., 2017).

\section{POSSIBLE CONNECTIONS BETWEEN DIFFERENT BASINS OF THE PARATETHYS}

A variety of studies (e.g., Łuczkowska, 1964; Ionesi, 1968; Paghida-Trelea, 1969; Popescu, 1975; Dumitrică et al., 1975; Brânzilă and Chira, 2005; Popescu-Guşă, 2006; Mikuž, 2009; ter Borgh et al., 2014) have noted the similarities between the latest Badenian and/or Early Sarmatian fossils from different basins of the Central Paratethys, and different gateways of communication across the Paratethys have recently been postulated (e.g., Palcu et al., 2017). It is still difficult to assess where the connections between distinctive basins such as the Carpathian Foredeep and Pannonian, Dacian, Transylvanian and Vienna basins were situated. Even more difficult to assess seem to be the factors that influenced the connectivity between different basins of the Central Paratethys (ter Borgh et al., 2013) since isolation of each basin took place at different times.

Our results contribute to these discussions, and suggest that during the latest Badenian and Early Sarmatian there were foraminiferal migratory routes between the northern and eastern parts of the Carpathian Foredeep Basin, since $\sim 45 \%$ of planktonic and $62 \%$ of benthic foraminiferal species are common to both regions during the latest Badenian while in the Early Sarmatian, $63 \%$ of planktonic and $80 \%$ of benthic species are the same. Additionally, some ostracod species (14, 31\%) were identified as being in common to these two basins during the Early Sarmatian. A possible connection between Carpathian Foredeep Basin and the Vienna Basin as well as between the Carpathian Foredeep Basin and the Pannonian Basin during the latest Badenian, which enabled planktonic and benthic foraminiferal migration, is also postulated based on the recently compiled micropalaeontological dataset. Surprisingly, there are more taxa in common between the Carpathian Foredeep Basin and the Vienna Basin (80\% of planktonic and $57 \%$ of benthic species are in common) than between the Carpathian Foredeep Basin and the Pannonian Basin (38\% of planktonic and $46 \%$ of benthic species are in common). Based on the common taxa identified in these basins we infer that the connection between the Carpathian Foredeep Basin and the Vienna Basin was more active, the connecting area being in the Eastern Alps and Western Carpathians junction (western Moravia) (Mandic, 2004; Holcová et al., 2015; Kováč et al., 2017). This interpretation seems to be consistent with the data, especially if the latest Badenian is linked with a significant transgression (Kováč et al., 2007).

While the suggested connection between the area studied and the Vienna Basin and the Pannonian Basin during the latest Badenian seemed to have been active, based on the the presence of a large share of planktonic species $(80 \%$ with the Vienna Basin and $38 \%$ with Pannonian Basin) we cannot demonstrate the same for the Early Sarmatian. Here, the benthic Sarmatian foraminifera are $47(59 \%)$ and $32(40 \%)$ in common for the area studied and the Vienna Basin and the Pannonian
Basin respectively, while the common planktonic foraminifera are missing from the area studied and from the Vienna Basin and Pannonian Basin. Therefore, there was probably no connectivity allowing planktonic foraminiferal migration during the Early Sarmatian. If the connections existed, they must have been quite shallow, allowing free migration of only benthic foraminifera and ostracods [16 ( 37\%) and $17(\sim 40 \%)$ of species having been recorded as common between the area studied and the VB and PB respectively].

POSSIBLE CONNECTION BETWEEN THE CENTRAL PARATETHYS AND THE MEDITERRANEAN REGION DURING THE LATEST BADENIAN

During the last few decades, several comparative palaeontological studies of various areas of the Central Paratethys and the Mediterranean realm have been carried out to find possible migration routes, though these have led to contradictory interpretations. Based on the presence of common ostracod fauna in the Central Paratethys and the Mediterranean, Szczechura $(1996,1997)$ postulated a possible connection between these two basins during the Late Badenian. The gastropod fauna from Slovenia (Mikuž, 2009) shows large similarities with fauns of different areas of the Central Paratethys, but also with the fauna from the Mediterranean and Atlantic region, as well as the echinoid fauna from the same area of the Central Paratethys (Ali and Mączyńska, 1986; Mikuž and Horvat, 2003). The connection seems to have been more active in the southern part of the Central Paratethys, while the northern part is considered to have been more restrictive to open-marine exchange (Kováčová et al., 2009). Based on a study of molluscs, salinity conditions and marine circulation in the Pannonian Basin, Kókay (1985: fig. 8, p. 46) considered that during some periods of the Late Badenian, the Central Paratethys communicated directly with the Mediterranean Sea, through its western part, across the area of today's Slovenia towards northern Italy. Moreover, Kókay (1985) excluded the possibility of communication through the Eastern Paratethys. The existence of the Slovenian Corridor (Trans-Tethyan Trench Corridor) has also been postulated by the nannofossil and gastropod studies of Bartol et al. (2012, 2014), who stated that the Central Paratethys and Mediterranean Sea were connected from the Late Badenian (Early Serravallian) until the Early Sarmatian. By contrast, Studencka et al. (1998), based upon bivalve studies, inferred that the Trans-Tethyan Trench Corridor was probably closed during the Late Badenian-Early Sarmatian and that the Central Paratethys directly communicated with the East Mediterranean Sea through the Axios-Vardar Trench. These authors further suggested that the Eastern Paratethys could also have communicated with the Mediterranean Sea through the reopened Arks straits. Rögl $(1998,1999)$ interpreted the presence of Indo-Pacific microfossil associations in the Central Paratethys as a result of a re-opening of seaways along the Pontides to Eastern Anatolia. Palaeogeographic connections to the Indo-Pacific area have also been indicated by Popescu (1975), Filipescu and Silye (2008), and Silye (2015).

The foraminiferal assemblages identified by us, together with published data, allow us to compare the Late Badenian foraminiferal assemblages across different basins of the Central Paratethys (Carpathian Foredeep, Vienna and Pannonian basins) as well as the foraminiferal assemblages of the Central Paratethys with that of the Mediterranean realm (equivalent to the Early Serravallian). In total, $52(\sim 26 \%)$ of 198 species are in common between the Central Paratethys and the Mediterra- 
nean realm (for details and references see Appendix 12). Among these, 21 out of 45 planktonic species and 31 out of 153 benthic ones are in common (for details see Appendix 12). Likewise, we identify ostrocod taxa (Cnestocythere lamellicosta, Cn. truncata, Cytheridea acuminata, Loxoconcha minima) in common between the Central Pararethys and the Mediterranean realm (see also Aiello and Szczechura, 2000).

The existence of some species of foraminifera in common between the Central Paratethys and the Mediterranean realm may support the idea of communication between these two realms during the Late Badenian-Early Serravallian; however, the exact location where the communication existed is difficult to assess, due to the poor sedimentological record (Báldi, 2006). However, the rare presence of relatively deep-dwelling foraminifera (Globorotalia) in the Central Paratethys may suggest that the connective corridor must have been shallow enabling migration of only the very shallow-planktonic foraminifera (e.g., Orbulina, Globigerina, Trilobatus, Globigerinella, Globigerinita), as well as benthic foraminifera and ostracods. However, a conection between the Central Paratethys and Indo-Pacific realm is not excluded by this study.

\section{CONCLUSIONS}

Integrated foraminiferal, ostracod and calcareous nannofossil studies were carried out on seven Middle Miocene sections in Poland, Romania, and the Republic of Moldova. Based upon micropalaeontological data, we have interpreted variable palaeoenvironmental conditions in the Carpathian Foredeep Basin during the latest Badenian and Early Sarmatian. Quantitative and qualitative changes in both foraminiferal (planktonic and benthic) and ostracod assemblages strongly support a significant sea level fall across the Badenian-
-Sarmatian boundary in both basins studied, causing a transformation from fully marine settings to marginal marine environments. During the Early Sarmatian, the salinity of the Carpathian Foredeep Basin was very variable, likely oscillating from brackish to fully marine, with episodes of hypersaline conditions. This inference is supported by the presence of fully marine calcareous nannofossil species in several Early Sarmatian intervals in the ECFB. The salinity variability within the basin, during the Early Sarmatian, was probably related to some minor sea level fluctuations, when short-lived near-fully marine conditions were re-established.

During the Early Sarmatian, the environment in the ECFB was mostly shallow in the backbulge area and slightly deeper in the foredeep part of the basin, where in some intervals the palaeodepth was probably around a few tens of metres, $<100 \mathrm{~m}$ in the foredeep depozone studied, and probably much less than $50 \mathrm{~m}$ in the backbulge depozone. Moreover, the foredeep depozone of the ECFB seems to have been deeper than that of the PCFB. The sea floor of the ECFB was characterized by generally oligotrophic conditions.

The Early-Late Sarmatian transition is interpreted as a period, at times, of low oxygen and deeper conditions in the Carpathian Foredeep Basin. The salinity of the Carpathian Foredeep Basin during the Early Sarmatian (Assemblages II, IV, V) was possibly close to normal marine.

Our studies indicate palaeoenvironmental similarity between different basins of the Central Paratethys but also support the earlier hypothesis of possible connections during the latest Badenian between different areas of the Central Paratethys as well as the existence of a gateway between the Central Paratethys and the Mediterranean realm.

Acknowledgements. We are indebted to M. Kaminski and four other anonymous reviewers for suggestions that helped us to considerably improve our manuscript.

\section{REFERENCES}

Aiello, G., Szczechura, J., 2000. Middle Miocene ostracods of the Fore-Carpathian Depression (Central Paratethys, Southwestern Poland). Bolletino della Società Paleontologica Italiana, 43: 11-39.

Alegret, L., Molina, E., Thomas, E., 2003. Benthonic foraminiferal turnover across the Cretaceous/Tertiary boundary at Agost (southeastern Spain): paleoenvironmental inferences. Marine Micropaleontology, 48: 251-279.

Alexandrowicz, S.W., Garlicki, A., Rutkowski, J., 1982. Podstawowe jednostki litostratygraficzne miocenu zapadliska przedkarpackiego (in Polish). Kwartalnik Geologiczny, 26 (2): $470-471$.

Ali, M.S.M., Mączyńska, S., 1986. Middle Miocene echinoids in the Tethys (Egypt) and the Paratethys (Poland). Neues Jahrbuch für Geologie und Paläontologie Monatshefte, (10): 577-586.

Avnaim-Katav, S., Almogi-Labin, A., Sandler, A., Sivan, D., 2013. Benthonic foraminifera as palaeoenvironmental indicators during the last million years in the eastern Mediterranean inner shelf. Palaeogeography, Palaeoclimatology, Palaeoecology, 386: $512-530$.

Backman, J., Pestieux, P., 1987. Pliocene Discoaster abundance variations, Deep Sea Drilling Project Site 606: biochronology and paleoenvironmental implications. Initial Reports of the Deep Sea Drilling Project, 94: 903-910.
Báldi, K., 1999. Taxonomic notes on benthic foraminifera from SW Hungary Middle Miocene (Badenian) Paratethys. Acta Geologica Hungarica, 42: 193-236.

Báldi, K., 2006. Paleoceanography and climate of the Badenian (Middle Miocene, 16.4-13.0 Ma) in the Central Paratethys based on foraminifera and stable isotope $\left(\delta^{18} \mathrm{O}\right.$ and $\left.\delta^{13} \mathrm{C}\right)$ evidence. International Journal of Earth Sciences, 95: 119-142.

Báldi, K., Velledits, F., Ćorić, S., Lemberkovics, V., Lőrincz, K., Lörincz, M., 2017. Discovery of the Badenian evaporites inside the Carpathian Arc: implications for global climate change and Paratethys salinity. Geologica Carpathica, 68: 193-206.

Barbot de Marny, N.P., 1866. Über der jüngere Ablagerungen des südlichen Russland. Sitzungsberichte der Wiener Akademie der Wissenschaften, 3, Abt. 1, (4): 339-342.

Bartol, M., Mikuž, V., Horvat, A., 2012. Paleontological evidence of communication between the Central Paratethys and the Mediterranean in the late Badenian/early Serravalian. In: RCMNS Interim Coloquium (eds. M. Stoica, M.C. Melinte-Dobrinescu and D. Palcu): 19-20. Bucharest.

Bartol, M., Mikuž, V., Horvat, A., 2014. Paleontological evidence of communication between the Central Paratethys and the Mediterranean in the late Badenian/early Serravalian. Palaeogeography, Palaeoclimatology, Palaeoecology, 394: 144-157.

Bé, A.W.H., 1977. An ecological, zoogeographic and taxonomic review of recent planktonic foraminifera. In: Oceanic Micro- 
paleontology (ed. A.T.S. Ramsey): 1-100. Academic Press, London.

Bé, A.W.H., Hamlin, W.H., 1967. Ecology of recent planktonic foraminifera. Part III. Distribution in the North Atlantic during the summer of 1962. Micropaleontology, 13: 87-106.

Bellanca, A., Sgarrella, F., Neri, R., Russo, B., Sprovieri, M., Bonaduce, G., Rocca, D., 2002. Evolution of the Mediterranean Basin during the Late Langhian-Early Serravallian: an integrated paleoceanographic approach. Rivista Italiana di Paleontologia e Stratigrafia, 108: 223-239.

Bicchi, E., Ferrero, E., Gonera, M., 2003. Palaeoclimatic interpretation based on Middle Miocene planktonic foraminifera: the Silesia Basin (Paratethys) and Monferrato (Tethys) records. Palaeogeography, Palaeoclimatology, Palaeoecology, 196: 265-303.

Bobrinskaya, O.G., 1967. Stratigrafia verkhnetortonskikh otlozhenii severo-zapada Moldavskii (verkhneye Priprut'ye) (in Russian). Bulletin of the Academy of Science of Modova. Paleontology and Stratigraphy, 4: 81-87.

Bobrinskaya, O.G., 1970. Ob usloviyakh obitaniya foraminifer i mshank $v$ pozdnetortonskom basseyne Moldaviyu (in Moldavian). In: Paleontologicheskiye issledovaniya verkhnego kaynozoya Moldavii (eds. K.N. Negadev-Nikonov, A.I. David, V.R. Roşca, M.M. Danici and P.V. Polev): 184-195. Academy of Science of Republic of Moldova, Chişinău.

Bobrinskaya, O.G., 2014. Distribution of the foraminifera from the Sarmatian deposits of Moldavian Platform (in Russian with English summary). Bulletin of the Geological and Seismological Institute of Academy of Sciences of Republic of Moldova, 1: 85-93.

Boltovskoy, E., Wright, R., 1976. Recent Foraminifera. Junk Publication, the Hague.

Bonaduce, G., Ciampo, G., Masoli, M., 1976. Distribution of Ostracoda in the Adriatic Sea. Pubblicazioni della Stazione Zoologica di Napoli 40 (suppl.): 1-304.

Brânzilă, M., 1999. The Geology of the Southern Part of the Moldavian Platform. Corson Press, lasi.

Brânzilă, M., 2004. Foraminifera assemblages of the backbulge depozone from the Moldavian Platform - the Basarabian. Acta Palaeontologica Romaniae, 4: 45-54.

Brânzilă, M., Chira, C., 2005. Microfossils assemblages from the Badenian/Sarmatian boundary in boreholes from the Moldavian Platform. Acta Palaeontologica Romaniae, 5: 17-26.

Brânzilă, M., Grasu, C., Olaru, L., Şaramet, M., Chira, C. Miclăuş, C., Ionesi, V., Țabără, D., Scutaru, C., 2005. Geological study for 25 samples of Bilca 2 core (micropaleontology, palinology and calcareous nannoplankton) and the correlation with the Bilca 1 core. $1-35$, Scientific report nr. 3828/2005. Iaşi.

Brânzilă, M., Chirilă, G., Jitaru, M., 2011. Micropalaeontologic content of the Sarmatian from southern Moldavian Platform - a backbulge depozone. Acta Palaeontologica Romaniae, 5: $45-59$

Breman, E., 1975. Ostracodes in a bottom core from the deep southeastern basin of the Adriatic Sea. I, II. Koninklijke Nederlandse Akademie van Wetenschappen, Proceeding, Ser. B, 78: 198-218.

Briceag, A., Ion, G., 2014. Holocene ostracod and foraminiferal assemblages of the Romanian Black Sea shelf. Quaternary International, 345: 119-129.

Bukry, D., 1974. Coccoliths as paleosalinity indicators - evidence from Black Sea. AAPG Memoir, 20: 353-363.

Cicha, I., 1960. The stratigraphic re-evaluation of the microfauna from southern Slovakia in relation with the Paratethys deposits (in Czech with English summary). Geologické Práce, 57: $159-216$

Cicha, I., 1998. The Vienna Basin. Abhandlungen der Senckenbergischen Naturforschenden Gesellschaft, 549: 43-45.

Cimerman, F., Langer, M., 1991. Mediterranean Foraminifera. Slovenska Akademija Znanosti in Umetnosti. Academia Scientiarum et Artium Slovencia Cl. 4, Historia Naturalis, 30.

Cornée, J.J., Moissette, P., Saint Martin, J.P., Kázmér, M., Tóth, E., Görög, A., Dulai, A., Müller, P., 2009. Marine carbonate systems in the Sarmatian (Middle Miocene) of the Central Paratethys: the Zsámbék Basin of Hungary. Sedimentology, 56 $1728-1750$

Corliss, B.H., Chen, C., 1988. Morphotype patterns of Norwegian Sea deep-sea benthonic foraminifera and ecological implications. Geology, 16: 716-719.

Culver, S.J., Mallinson, D.J., Corbett, D.R., Leorri, E., Rouf, A.A., Shazili, N.A.M., Yaacob, R., Whittaker, J.E., Buzas, M.A., Parham, P.R., 2012. Distribution of Foraminifera in the Setiu Estuary and Lagoon, Terengganu, Malaysia. Journal of Foraminiferal Research, 42: 109-133.

Czepiec, I., Kotarba, M.J., 1998. Paleoecology and organic matter in the Late Badenian and Early Sarmatian marine basin of the Polish part of the Carpathian Foredeep. Przegląd Geologiczny, 46: 32-36.

DeCelles, P.G., Giles, K.A., 1996. Foreland basin systems. Basin Research, 8: 105-123.

De Leeuw, A., Bukowski, K., Krijgsman, W., Kuiper, K.F., 2010. Age of the Badenian salinity crisis; impact of Miocene climate variability on the circum - Mediterranean region. Geology, 39: 715-718.

Dondi, L., 1963. Nota paleontologica-stratigrafica sul Pedeappennino padano (in Italian). Bollettino della Società Geologica Italiana, 81: 113-229.

Drinia, H., Antonarakou, A., Tsaparas, N., 2004. Diversity and abundance trends of benthonic foraminifera from the southern part of the Iraklion Basin, Central Crete. Bulletin of the Geological Society of Greece 36: 772-781.

Drinia, H., Antonarakou, A., Tsourou, T., Kontakiotis, G., Psychogiu, M., Anastasakis, G., 2016. Foraminifera ecobiostratigraphy of the southern Evoikos outer shelf, central Aegean Sea, during MIS 5 to present. Continental Shelf Research, 126: 36-49

Dubicka, Z., Peryt, D., Szuszkiewicz, M., 2014. Foraminiferal evidence for paleogeographic and paleoenvironmental changes across Coniacian-Santonian boundary in western Ukraine. Palaeogeography, Palaeoclimatology, Palaeoecology, 401: $43-56$

Dubicka, Z., Złotnik, M., Borszcz, T., 2015. Test morphology as a function of behavioral strategies - inferences from benthonic foraminifera. Marine Micropaleontology, 116: 38-49.

Duleba, W., Debenay, J.P., Eichler, B.B., Mahiques, M.M., 1999. Holocene environmental and water circulation changes: Foraminifer morphogroups evidence in Flamengo Bay (SP, Brazil). Journal of Costal Research, 15: 554-571.

Dumitrică, P., Gheta, N., Popescu, G., 1975. New data on the biostratigraphy and correlation of the Middle Miocene in the Carpathian area. Institute of Geology and Geophysics, Notes of the meetings, Bucharest, 61: 65-84.

Dumitriu, S.D., Loghin, S., Dubicka, Z., Melinte-Dobrinescu, M.C., Paruch-Kulczycka, J., Ionesi, V., 2017. Foraminiferal, ostracod, and calcareous nannofossil biostratigraphy of the latest Badenian-Sarmatian interval (Middle Miocene, Paratethys) from Poland, Romania and Republic of Moldova. Geologica Carpathica, 68: 419-444

Dumitriu, S.D., Dubicka, Z., lonesi, V., 2018. The functional significance of the spinose keel structure of benthonic foraminifera: inferences from Miliolina cristata Millett, 1898 (Miliolida) from northeast Romania. Journal of Micropalaeontology, 37: 153-166.

Filipescu, S., Silye, L., 2008. New Paratethyan biozones of planktonic foraminifera described from the Middle Miocene of the Transylvanian Basin (Romania). Geologica Carpathica, 59: 537-544.

Filipescu, S., Popa, M., Wanek, F., 1999. The significance of some Sarmatian faunas from the southwestern part of the Pădurea Craiului Mountains (Romania). Acta Palaeontologica Romaniae, 2: 163-169.

Filipescu, S., Silye, L., Krézsek, C., 2005. Sarmatian micropaleontological assemblages and sedimentary paleoenvironments in the southern Transylvanian Basin. Acta Palaeontologica Romaniae, 5: 173-179. 
Filipescu, S., Miclea, A., Gross, M., Harzhauser, M., Zagorsek, K., Jipa, C., 2014. Early Sarmatian paleoenvironments in the easternmost Pannonian Basin (Borod Depression, Romania) revealed by the micropaleontological data. Geologica Carpathica, 65: 67-81.

Fordinál, K., Zágoršek, K., Zlinská, A., 2006. Early Sarmatian biota in the northern part of the Danube Basin (Slovakia). Geologica Carpathica, 57: 123-130.

Foresi, L.M., Bonomo, S., Caruso, A., Di Stefano, E., Salvmorini, G., Sprovieri, R., 2002. Calcareous plankton high-resolution biostratigraphy (foraminifera and nannofossils) of the Uppermost Langhian-Lower Serravallian Ras il-Pellegrin section (Malta). Rivista Italiana di Paleontologia e Stratigrafia, 108: 195-210.

Garecka, M., Olszewska, B., 2011. Correlation of the Middle Miocene deposits in SE Poland and Western Ukraine based on foraminifera and calcareous nannoplankton. Annales Societatis Geologorum Poloniae, 81: 309-330.

Gebhardt, H., Zorn, I., Roetzel, R., 2009. The initial phase of the Early Sarmatian (Middle Miocene) transgression. Foraminiferal and ostracod assemblages from incised valley fill in the Molasse Basin of Lower Austria. Austrian Journal of Earth Science, 102: 100-119.

Gedl, P., Peryt, D., 2011. Dinoflagellate cyst, palynofacies and foraminiferal records of environmental changes related to the Late Badenian (Middle Miocene) transgression at Kudryntsi (western Ukraine). Annales Societatis Geologorum Poloniae, 81: 331-349.

Gedl, P., Peryt, D., Peryt, T.M., 2016. Foraminiferal and palynological organic matter records of the Upper Badenian (Middle Miocene) deposits at Anadoly (marginal part of the Ukrainian Carpathian Foredeep Basin). Geological Quarterly, 60 (2): 517-536.

Gonera, M., Peryt, T.M., Durakiewicz, T., 2000. Biostratigraphical and paleoenvironmental implications of isotopic studies ${ }^{18} \mathrm{O},{ }^{13} \mathrm{C}$ of Middle Miocene (Badenian) foraminifers in the Central Paratethys. Terra Nova, 12: 231-238.

Grasu, C., Miclăuş, C., Brânzilă, M., Boboş, I., 2002. The Sarmatian of the Foreland System Basin of the Eastern Carpathians. Tehnique Press, Bucharest.

Gross, M., 2006. Mittelmiozäne Ostracoden aus dem Wiener Becken (Badenium/Sarmatium, Österreich). Österreichische Akademie der Wissenschaften Schriftenreihe der Erdwissenschaftlichen Kommissionen special, 1: 1-224.

Grunert, P., Soliman, A., Corič, S., Roetzel, R., Harzhauser, M., Piller, W.E., 2012. Facies development along the tide-influenced shelf of the Burdigalian Seaway: an example from the Ottnangian stratotype (Early Miocene, middle Burdigalian). Marine Micropaleontology, 84-85: 14-36.

Hartmann, G., 1975. Ostracoda. In: Dr. H. G. Bronns Klassen und Ordnungen des Tierreichs (ed. H.E. Gruner): 569-786. 5 Arthropoda, Abt. 1 Crustacea, Buch 2, Teil 4, Lieferung 4, Gustav Fischer, Jena.

Harzhauser, M., Piller, W.E., 2004. Integrated stratigraphy of the Sarmatian (Upper Middle Miocene) in the western Central Paratethys. Stratigraphy, 1: 65-86.

Harzhauser, M., Piller, W.E., 2007. Benchmark data of a changing sea-palaeogeography, palaeobiogeography and events in the Central Paratethys during the Miocene. Palaeogeography, Palaeoclimatology, Palaeoecology, 253: 8-31.

Harzhauser, M., Kroh, A., Mandic, O., Piller, W.E., Göhlich, U., Reuter, M., Berning, B., 2007. Biogeographic responses to geodynamics: a key study all around the Oligo-Miocene Tethyan Seaway. Zoologischer Anzeiger, 246: 241-256.

Hayward, B.W., Hollis, C., 1994. Brackish foraminifera in New Zealand: a taxonomic and ecologic review. Micropaleontology, 40: 185-222.

Hemleben, C., Spindler, M., Anderson, O.R., 1989. Modern Planktonic Foraminifera. New York, Springer

Hilgen, F.J., Abdul Aziz, H., Krigjsman, W., Raffi, I., Turco, E., 2003. Integrated stratigraphy and astronomical tuning of the Serravallian and lower Tortonian at Monte dei Corvi (middle-up- per Miocene, northern Italy). Palaeogeography, Palaeoclimatology, Palaeoecology, 199: 229-264.

Holcová, K., Brzobohatý, R., Kopecká, J., Nehyba, S., 2015. Reconstruction of the unusual Middle Miocene (Badenian) palaeoenvironment of the Carpathian Foredeep (Lomnice/Tišnov denudational relict, Czech Republic). Geological Quarterly, 59 (4): 654-678

Hudáčková, N., Banasová, M., Halásová, E., Reháková, D., Lintnerová, O., 2003. Distribution of planktonic and benthonic foraminifera in correlation with calcareous dinocysts derived from the Devínska Nová Ves clay pit and their evidence for environmental reconstruction sequence and Biostratigraphy. In Birth of the New World, Abstract book of the ESF-EEDEN Conference, 41-43. Bratislava, Comenius University.

Hudáčkova, N., Soták, J., Ruman, A., Rybár, S., Milovsky, R., 2018. Marsh-type agglutinated foraminifera from Upper Miocene sediments of the Danube Basin. Micropaleontology, 64: 481-492.

led, I.M., Holcová, K., Abd-Elshafy, E., 2011. Biostratigraphy and paleoecology of the Burdigalian - Serravallian sediments in Wadi Sudr (Gulf of Suez, Egypt): comparison with the Central Paratethys evolution. Geologica Carpathica, 62: 233-249.

Iljina, L.B., 2000. On connection between basins of the Eastern Paratethys and adjacent seas in the Middle and Late Miocene. Stratigraphy and Geological Correlations, 8: 300-305.

Ionesi, B., 1968. Stratigrafia depozitelor miocene de platformă dintre Valea Siretului şi Valea Moldovei (Plarforma Moldovenească) (in Romanian). Academy Press, Bucharest.

Ionesi, B., 1991. Biozonation of the Sarmatian from Moldavian Platform. The celebration days of "Al. I. Cuza" University of Iaşi, (25-26 X 1991) - conference paper.

Ionesi, B., Guevara, I., 1993. The study of the Sarmatian deposits of 1002 Bădeuţi Core (NV Moldavian Platform). Bulletin of Romanian Geological Society, 14: 79-87.

Ionesi, B., Ionesi, L., 1968. Contributions to the knowledge of the Buglovian between Siret Valley and Suceava Valley (Moldavian Platform). Scientific Annales of "Al. I. Cuza" University of Iaşi, Geography-Geology, 14: 67-78.

Ionesi, L., 1994. Geologia unităților de platformă şi a Orgenului Nord-Dobrogean (in Romanian). Technique Press, Bucharest.

Ionesi, L., Ionesi, B., 1981. New data on the Sarmatian deposits from the north-east part of the Moldavian Platform (Hudeşti-Mitoc). Romanian Academy Press, The Memoirs of the Scientific Section, 4: 337-351.

Ionesi, L., Ionesi, B., 1982. Contributions à l'étude du Buglovien d'entre Baseu et Prut (Platforme Moldave). Scientific Annales of "Al. I. Cuza" University of lasi, Geography-Geology, 2: 29-38

Ionesi, L., Ionesi, B., Rosca, V., Lungu, A., Ionesi, V., 2005. Sarmaţianul mediu şi superior de pe Platforma Moldovenească (in Romanian). Romanian Academy Publisher, Bucharest.

Ionesi, V., 2006. Sarmaţianul dintre Valea Siretului şi Valea Şomuzului Mare (in Romanian). "Al. I. Cuza" Univeristy Press, laşi.

Jiříček, R., 1974. Biostratigraphische Bedeutung der Ostracoden des Sarmats s. str. In: Chronostratigraphie und Neostratotypen Miozan der Zentralen Paratethys (ed. E. Brestenská): 434-158. Veda, Bratislava.

Jiříček, R., 1983. Redefinition of the Oligocene and Neogene Ostracod Zonation of the Paratethys. Miscellanea Micropaleontology. A memorial volume dedicated to the 18th European Colloquium on Micropaleontology: 195-236.

Jorissen, F.J., de Stigter, H.C., Widmark, J.G.V., 1995. A conceptual model explaining benthonic foraminiferal microhabitats. Marine Micropaleontology, 26: 3-15.

Kaiho, K., 1991. Global changes of Paleogene aerobic/anaerobic benthonic foraminifera and deep-sea circulation. Palaeogeography, Palaeoclimatology, Palaeoecology, 83: 65-85.

Kaiho, K., 1999. Effect of organic carbon flux and dissolved oxygen on the benthonic foraminiferal oxygen index (BFOI). Marine Micropaleontology, 37: 67-76.

Keller, G., 1985. Depth stratification of planktonic foraminifers in the Miocene Ocean. GSA Memoirs, 163: 177-195. 
Kókay, J., 1985. Central and Eastern Paratethys interrelations in the light of the Late Badenian salinity conditions. Geologica Hungarica, 48: 7-95.

Kollmann, K., 1960. Cytherideinae und Schulerideinae n. subfam. (Ostracoda) aus dem Neogen des ostl. Oesterreich. Mitteilungen der Geologischen Gesellschaft in Wien, 51 (1958): 89-195.

Koubová, I., Hudáčková, N., 2010. Foraminiferal successions in the shallow water Sarmatian sediments from the MZ 93 borehole (Vienna Basin, Slovak part). Acta Geologica Slovaca, 2: 47-58.

Kováč, M., 2000. Geodynamic, Paleogeographic and Structural Development of the Carpatho-Pannonian Region during the Miocene: New View on the Neogene Basins of Slovakia. Veda, Bratislava.

Kováč, M., Andreyeva-Grigorovich, A., Bajraktarević, Z., Brzobohatý, R., Filipescu, S., Fodor, L., Harzhauser, M., Nagymarosy, N., Oszczypko, N., Pavelić, D., Rögl, F., Saftić, B., Sliva, U., Studencka, B., 2007. Badenian evolution of the Central Paratethys Sea: paleogeography, climate and eustatic sea-level changes. Geologica Carpathica, 58: 579-606.

Kováč, M., Hudáčková, N., Halásová, E., Kováčová, M., Holcová, K., Oszczypko-Clowes, M., Báldi, K., Less, G., Nagymarosy, A., Ruman, A., Klučiar, T., Jamrich, M., 2017. The Central Paratethys palaeoceanography: a water circulation model based on microfossil proxies, climate, and changes of depositional environment. Acta Geologica Slovaca, 9: 75-114.

Kováčová, P., Hudáčková, N., 2009. Late Badenian foraminifers from Vienna Basin (Central Paratethys): stable isotope study and paleoecological implications. Geologica Carpathica, 60: $59-70$

Kováčová, P., Laurent, E., Hudáčková, N., Renard, M., 2009. Central Paratethys paleoenvironment during the Badenian (Middle Miocene): evidence from foraminifera and stable isotope $\left(\delta^{13} \mathrm{C}\right.$ and $\left.\delta^{18} \mathrm{O}\right)$ study in the Vienna Basin (Slovakia). International Journal of Earth Science, 98: 1109-1127.

Krzywiec, P., 2001. Contrasting tectonic and sedimentary history of the central and eastern parts of the Polish Carpathian Foredeep basin - results of seismic data interpretation. Marine and Petroleum Geology, 18: 13-38.

Krzywiec, P., Wysocka, A., Oszczypko, N., Mastalerz, K., Papiernik, B., Wróbel, G., Oszczypko-Clowes, M., Aleksandrowski, P., Madej, K., Kijewska, S., 2008. Evolution of the Miocene deposits of the Carpathian Foredeep in the vicinity of Rzeszów (the Sokołów-Smolarzyny 3D seismic survey area) (in Polish with English summary). Przegląd Geologiczny, 56: 232-244.

Langer, M.R., 1993. Epiphytic foraminifera. Marine Micropaleontology, 20: 235-265.

Latal, C., Piller, W.E., Harzhauser, M., 2004. Paleoenvironmental reconstructions by stable isotopes of Middle Miocene gastropods of the Central Paratethys. Palaeogeography, Palaeoclimatology, Palaeoecology, 211: 157-169.

Leckie, R.M., 1987. Paleoecology of mid-Cretaceous planktonic foraminifera: a comparison of open ocean and epicontinental sea assemblages. Micropaleontology, 33: 164-176.

Lelek, D., Oszczypko-Clowes, M., Oszczypko, N., 2010. Some remarks of the biostratigraphy and paleoecology of the Middle Miocene Machów Formation (Carpathian Foredeep, Poland). Geologica Balcanica, 39: 228-229.

Licari, L., Schumacher, S., Wenzhoefer, F., Zabel, M., Mackensen, A., 2003. Communities and microhabitats of living benthonic foraminifera from the tropical east Atlantic: impact of different productivity regimes. Journal of Foraminiferal Research, 33: 10-31.

Liebau, A., 1975. Comments on suprageneric taxa of the Trachyleberididae s.n. (Ostracoda, Cytheracea). Neues Jahrbuch für Geologie und Paläontologie, Abhandlungen, 148: 353-379.

Lowery, C.M., Leckie, M.R., Sageman, B.B., 2017. Micropaleontological evidence for redox changes in the OAE3 inter- val of the US Western Interior: Global vs. local processes. Cretaceous Research, 69: 34-48.

Lukina, T., 2001. Foraminifera of the Laptev Sea. Protistology, 2: 105-122.

Łuczkowska, E., 1964. The micropaleontological stratigraphy of the Miocene in the region of Tarnobrzeg-Chmielnik (in Polish with English summary). Prace Geologiczne, 20: 1-52.

Łuczkowska, E., 1972. Miliolidae (Foraminiferida) from Miocene of Poland, part I. Revision of the classification. Acta Palaeontologica Polonica, 17: 342-377.

Łuczkowska, E., 1974. Miliolidae (Foraminiferida) from Miocene of Poland. Part II. Biostratigraphy, Paleoecology and Systematics. Acta Palaeontologica Polonica, 19: 1-176.

Maissuradze, L., Koiava, K., 2011. Biodiversity of Sarmatian Foraminifera of the Eastern Paratethys. Bulletin of the Georgian Academy of Sciences, 5: 143-151.

Maissuradze, L., Koiava, K., Kvaliashili, L., Spezzaferri, S., 2014. Biodiversity, evolution and biostratigraphic significance of Konkian foraminifers of Euxine Caspian Basin of Eastern Paratethys. Proceedings of the Georgian National Museum, 6: 9-22.

Mandic, O., 2004. Foraminiferal paleoecology of a submarine swell - the Lower Badenian (Middle Miocene) of the Mailberg Formation at the Buchberg in the Eastern Alpine Foredeep: initial report. Annalen des Naturhistorischen Museums in Wien, 105 (A): 161-174.

Mateu-Vicens, G., Box, A., Deudero, S., Rodríguez, B., 2010. Comparative analysis of epiphytic foraminifera in sediments colonized by seagrass Posidonia oceanica and invasive macroalgae Caulerpa spp. Journal of Foraminiferal Research, 40: $134-147$.

Mărunteanu, M., 1999. Litho- and biostratigraphy (calcareous nannoplankton) of the Miocene deposits from the Outer Moldavides. Geologica Carpathica, 50: 313-324.

Melinte-Dobrinescu, M.C., Ion, G., 2013. Emiliania huxleyi fluctuations and associated microalgae in superficial sediments of the Romanian Black Sea shelf. Geo-Eco-Marina, 19: 129-135.

Melinte-Dobrinescu, M.C., Stoica, M., 2013. Badenian calcareous nannofossil fluctuation in the Eastern Carpathians: palaeoenvironmental significance. Acta Palaeontologica Romaniae, 9: 47-56.

Mészáros, N., 1992. Nannofossil zones in the Paleogene and Miocene deposits of the Transylvanian Basin. Knihovnicka ZPN, 14b: 87-92.

Miclăuş, C., Grasu, C., Juravle, A., 2011. Sarmatian (Middle Miocene) coastal deposits in the wedge-top depozone of the Eastern Carpathian Foreland Basin System. A case study. Scientific Annales of "Al. I. Cuza" University of Iaşi, Geography-Geology, 57: 75-90.

Miculan, P., 1994. Planktonic foraminiferal biostratigraphy of the middle Miocene in Italy. Bollettino della Società Paleontologica Italiana, 33: 299-339.

Mikuž, V., 2009. Miocene gastropods from the vicinity of Sentjernej and from other localities in the Krka basin, Slovenia. Folia Biologica et Geologica, 50: 5-70.

Mikuž, V., Horvat, A., 2003. Paleobiogeografija klipeastrov (Echinoidea). Geološki Zbornik, 17: 119-123.

Murray, J.W., 1968. Living foraminifers of lagoons and estuaries. Micropaleontology, 14: 435-455

Murray, J.W., 1991. Ecology and Paleoecology of Benthonic Foraminifera. Longman Scientific and Technical, Essex.

Murray, J.W., 2006. Ecology and Applications of Benthonic Foraminifera. Cambridge University Press, New York.

Nagy, J., Kaminski, M.A., Kuhnt, W., Bremer, M., 2000. Agglutinated foraminifera from neritic to bathyal facies in the Paleogene of Spitsbergen and the Barents Sea. Grzybowski Foundation Special Publication, 7: 333-361.

Nevesskaja, L.A., Popov, S.V., Goncharova, I.A., Iljina, L.B., Paramonova, N.P., 2006. Accelerated evolution of the Eastern Paratethys mollusks under condition of decreased competition. 
In: Evolution of Biosphere and Bioorigins (ed. S.V. Rozhnov): 334-358. Nauka Press, Moscow.

Ney, R., Burzewski, W., Bachleda, T., Górecki, W., Jakóbczak, K., Słupczyński, K., 1974. Outline of paleogeography and evolution of lithology and facies of Miocene layers on the Carparhian Foredeep (in Polish with English summary). Prace Geologiczne, 82: 3-65.

Olszewska, B., 1999. Biostratigraphy of Neogene in the Carpathian Foredeep in the light of new micropaleontological data (in Polish with English summary). Prace Państwowego Instytutu Geologicznego, 168: 9-28.

Odrzywolska-Bieńkowa, E., 1966. Micropalaeontological stratigraphy of the Miocene in the north-eastern margin of the Carpathian Fore deep (in Polish with English summary). Kwartalnik Geologiczny, 10 (2): 432-441.

Odrzywolska-Bieńkowa, E., 1972. Micropalaeontological stratigraphy of the younger Tertiary in the bore hole Dzwola, Roztocze area (in Polish with English summary). Kwartalnik Geologiczny, 16 (3): 669-675.

Odrzywolska-Bieńkowa, E., 1974. The results of micropaleontological studies on the Miocene drillings in the Stopnica area (Central Poland) (in Polish with English summary). Kwartalnik Geologiczny, 22 (1): 81-83.

Oszczypko, N., 1998. The Western Carpathian Foredeep - development of foreland basin in front of accretionary wedge and its burial history (Poland). Geologica Carpathica, 49: 415-431.

Oszczypko, N., 2006. Late Jurassic-Miocene evolution of the Outer Carpathian fold-and-thrust belt and its foredeep basin (Western Carpathians, Poland). Geological Quarterly, 50 (1): 169-194.

Oszczypko, N., Oszczypko-Clowes, M., 2012. Stages of development in the Polish Carpathian Foredeep Basin. Central European Journal of Geosciences, 4: 138-162.

Oszczypko-Clowes, M., Lelek, D., Oszczypko, N., 2012. Sarmatian paleoecological environment of the Machów Formation based on the quantitative nannofossil analysis - a case study from the Sokołów area (Polish Carpathian Foredeep). Geologica Carpathica, 63: 267-294.

Oszczypko, N., Krzywiec, P., Popadyuk, I., Peryt, T., 2006. Carpathian Foredeep Basin (Poland and Ukraine): its sedimentary, structural, and geodynamic evolution. AAPG Memoir, 84: 293-350.

Paghida-Trelea, N., 1969. Microfauna Miocenului dintre Siret şi Prut (in Romanian). Romanian Academy Publsiher, Bucharest.

Paghida-Trelea, N., Simionescu, T., Costeschi, G., 1970. Ostracodele miocene din Podişul Moldovenesc (in Romanian). Scientific Annales of "Al. I. Cuza" University of laşi, Geography-Geology, 2: 107-120.

Palcu, D., Tulbure, M., Bartol, M., Kouwenhoven, M., Krijgsman, W., 2015. The Badenian-Sarmatian Extinction Event in the Carpathian foredeep basin of Romania: paleogeographic changes in Paratethys domain. Global and Planetary Change, 133: 346-358.

Palcu, D.V., Golovina, L.A., Vernyhorova, Y.V., Popov, S.V., Krijgsman, W., 2017. Middle Miocene paleoenvironmental crises in Central Eurasia caused by changes in marine gateway configuration. Global and Planetary Change, 158: 57-71.

Papp, A., 1954. Die Mollusken fauna im Sarmat des Wiener Beckens. Mitteilungen der Geologischen Gesellschaft in Wien, 45: $1-112$

Papp, A., 1956. Fazies und Gliederung des Sarmat des Wiener Beckens. Mittelungen der Geologischen Gessellschaft in Wien, 47: 35-98.

Papp, A., 1974. Die Entwicklung des Sarmats in Österreich. In: Chronostratigraphie und Neostratotypen, Miozän der Zentralen Paratethys (ed. E. Brestenská): 75-77. Verlag der Slowakischen Akademie der Wissenschaften, Bratislava, IV.

Paramonova, N.P., 1995. Zoogeografiya Paratetisa v sarmatskoye vremya (in Russian). In: Ekosistemnyye perestroyki i evolutsiya biosfery (eds. A.Y. Rozanov and M.A. Semikhatov): 137-141. The Paleontological Institute Press, Moscow.
Pawlewicz, M., 2006. Total petroleum systems of the North Carpathian Province of Poland, Ukraine, Czech Republic, and Austria. U.S.G.S. Bulletin, 2204 (D): 1-26.

Pérez-Asensio, J., Aguirre, J., Schmiedel, G., Civis, J., 2012. Impact of restriction of the Atlantic-Mediterranean gateway on the Mediterranean outflow water and eastern Atlantic circulation during the Messinian. Paleoceanography, 27: 1-14.

Peryt, D., 1997. Calcareous nannoplankton stratigraphy of the Middle Miocene in the Gliwice area (Upper Silesia, Poland). Bulletin of Polish Academy of Earth Sciences, 45: 119-131.

Peryt, D., 2013. Foraminiferal record of the Middle Miocene climate transition prior to the Badenian salinity crisis in the Polish Carpathian Foredeep Basin (Central Paratethys). Geological Quarterly, 57 (1): 141-164.

Peryt, D., Gedl, P., 2010. Palaeoenvironmental changes preceding the Middle Miocene Badenian salinity crisis in the northern Polish Carpathian Foredeep Basin (Borków quarry) inferred from foraminifers and dinoflagellate cysts. Geological Quarterly, $\mathbf{5 4}$ (4): 487-508

Peryt, D., Jasionowski, M., 2012. Sarmatian foraminiferal assemblages of cavern fillings in the Badenian reefs of Medobory (Polupanivka, western Ukraine). Biuletyn Państwowego Instytutu Państwowego, 449: 175-184.

Peryt, D., Gedl, P., Peryt, T., 2014. Foraminiferal and palynological records of the Late Badenian (Middle Miocene) transgression in Podolia (Shchyrets near Lviv, western Ukraine). Geological Quarterly, 58 (3): 445-464.

Peryt, T.M., 2006. The beginning, development and termination of the Middle Miocene Badenian salinity crisis in Central Paratethys. Sedimentary Geology, 188-189: 179-196.

Pezelj, Đ., Sremac, J., Sokač, A., 2007. Palaeoecology of the Late Badenian foraminifera and ostracoda from the SW Central Paratethys (Medvednica Mt., Croatia). Geologia Croatica, 60: 139-150.

Pezelj, Đ., Mandic, O., Ćorić, S., 2013. Paleoenvironmental dynamics in the southern Pannonian Basin during initial Middle Miocene marine flooding. Geologica Carpathica, 64: 81-100.

Pezelj, Đ., Sremac, J., Bermanec, V., 2016. Shallow-water benthonic foraminiferal assemblages and their response to the paleoenvironmental changes - example from the Middle Miocene Medvednica Mt. (Croatia, Central Paratethys). Geologica Carpathica, 67: 329-345.

Phillip, G., Imam, M.M., Abdel Gawad, G.I., 1997. Planktonic foraminiferal biostratigraphy of the Miocene sequence in the area between Wadi El-Tayiba and Wadi Sidri, west central Sinai, Egypt. Journal of African Earth Sciences, 25: 435-451.

Piller, W.E., Harzhauser, M., 2005. "The myth of the brackish Sarmatian Sea". Terra Nova, 17: 450-455.

Pisera, A., 1996. Miocene reefs of the Paratethys: a review. SEPM, Concepts in Sedimentology and Paleontology, 5: 97-104.

Popescu, G., 1975. Foraminiferal study of the Lower and Middle Miocene from north-western Transylvania. Memoire of Geological and Geophysical Institute, 23: 1-121.

Popescu-Guşă, C.T., 2006. Studiul palinologic şi microfaunistic al Badenianului din Platforma Moldovenească şi Dobrogea de Sud (in Romanian). Ph.D. thesis, "Al. I. Cuza" University of laşi.

Popov, S.V., Rögl, F., Rozanov, A.Y., Steinger, F.F., Shcherba, I.G., Kováč, M., 2004. Lithological-paleogeographic maps of Paratethys. 10 maps, Late Eocene to Pliocene. Courier Forschungsinstitut Senckenberg, 250: 1-46.

Popov, S.V., Nevesskaja, L.A., Goncharova, I.A., Iljina, L.B., 2005. Eastern Paratethys biogeography during Neogene based on mollusks. Transactions of the Geological Institute Russian Academy of Sciences, 516: 309-337.

Rathburn, A.E., Corliss, B.H., 1994. The ecology of living (stained) deep-sea benthic foraminifera from the Sulu Sea. Paleoceanography, 9: 87-150.

Rögl, F., 1998. Palaeogeographic considerations for Mediterranean and Paratethys seaways (Oligocene to Miocene). Annalen des Naturhistorischen Museums in Wien, 99 (A): 279-310. 
Rögl, F., 1999. Mediterranean and Paratethys. Facts and hypotheses of an Oligocene to Miocene paleogeography (short overview). Geologica Carpathica, 50: 339-349.

Rögl, F., Müller, C., 1976. Das Mittelmiozän und die Baden-Sarmat Grenze in Walbersdorf (Burgenland). Annalen des Naturhistorischen Museums in Wien, 80: 221-232.

Rögl, F., Spezzaferri, S., 2003. Foraminiferal paleoecology and biostratigraphy of the Mülhbach section (Gaindorf Formation, Lower Badenian). Annalen des Naturhistorischen Museums in Wien, 104 (A): 23-75.

Rögl, F., Steininger, F.F., 1984. Neogene Paratethys, Mediterranean and Indo-Pacific Seaways. In: Fossils and Climate (ed. P.J. Brenchley): 171-200. London, Wiley.

Ruggieri, G., 1950. Gli ostracodi delle sabbie grigie quaternarie (Milazziano) di Imola (in Italian). Parte I. Giornale di Geologia, 21: 1-57.

Ruman, A., Rybár, S., Hudáčková, N., Šujan, M., Halásová, E., 2017. Depositional environment changes during the early-late Serravallian boundary dated by the Central Paratethys bioevents. Facies, 63: 2-13.

Russo, B., Sgarrella, F., Gaboardi, S., 2002. Benthonic foraminifera as indicators of paleoecological bottom conditions in the Serravallian Tremiti sections (Eastern Mediterran, Italy). Rivista Italiana di Paleontologia e Stratigrafia, 108: 275-287.

Schiebel, R., Hemleben, C., 2005. Modern planktonic foraminifera. Paläontologische Zeitschrift, 79: 135-148

Schiebel, R., Hemleben, C., 2017. Planktonic foraminifers in the modern oceans. Heidelberg, Springer.

Schütz, K., Harzhauser, M., Rogl, F., Coric, S., Galovic, I., 2007. Foraminiferen und Phytoplanktonaus dem unteren Sarmatium des siidlichen Wiener Beckens (Petronell, Niederösterreich). Jahrubuch der Geologichen Bundesansalt, 147: 449-488.

Sen Gupta, B.K., Machain-Castillo, M.L., 1993. Benthonic foraminifera in oxygen-poor habitats. Marine Micropaleontology, 20: 183-201.

Seneš, J., 1960. Entwicklungsgeschichte der Paratethys. Mitteilungen der Österreichischen Geologischen Gesellschaft Wien, $\mathbf{5 2}$ 181-187.

Seneš, J., 1988. La Paratéthys, la Mer Transeuropéenne: une revue actuelle. Geologický Zborník Geologica Carpathica, 39: 563-568.

Silye, L., 2015. Sarmatian Foraminiferal Assemblages from Southern Transylvanian Basin and their Significance for the Reconstruction of Depositional Environments. University Press, Cluj.

Simionescu, I., 1902. Constituţiunea geologică a ţărmului Prutului din Nordul Moldovei (in Romanian). Publicaţiunile Fondului Vasile Adamachi, 2: 27-53

Simionescu, I., 1903. Contributiuni la geologia Moldovei dintre Siret şi Prut (in Romanian). Publicaţiunile Fondului Vasile Adamachi, 2: 7-117.

Steininger, F.F., Rögl, F., 1985. Paleogeography and palinspastic reconstruction of the Neogene of the Mediterranean and Paratethys. Geological Society Special Publications, 17: 659-668.

Stoica, M., Lazăr, I., Krijgsman, W., Vasiliev, I., Jipa, D., Floroiu, A., 2013. Paleoenvironmental evolution of the East Carpathian foredeep during the late Miocene-early Pliocene (Dacian Basin; Romania). Global and Planetary Change, 103: 135-148.

Studencka, B., Jasionowski, M., 2011. Bivalves from the Middle Miocene reefs of Poland and Ukraine: a new approach to Bade-
nian/Sarmatian boundary in the Paratethys. Acta Geologica Polonica, 61: 79-114.

Studencka, B., Goncharova, I.A., Popov, S.V., 1998. The bivalve fauna as a basis for reconstruction of the Middle Miocene history of Paratethys. Acta Geologica Polonica, 48: 285-342.

Szczechura, J., 1996. Ecological control of ostracode distribution in the Miocene of Paratethys. In: Proceedings of the Second European Ostracod Meeting (ed. M.C. Keen): 99-106. University of Glasgow, Scotland, 23-27 July. British Micropaleontology Society, London.

Szczechura, J., 1997. The distribution of Triebelina raripila and Carinocyihere ixcurinata (Ostracoda) from the Middle Miocene of the Central Paratethys and their palaeogeographic implications. Journal of Micropalaeontology, 16: 1-7

Szczechura, J., 2000. Age and evolution of depositional environments of the supra-evaporitic deposits in the northern, marginal part of the Carpathian Foredeep: micropaleontological evidence. Geological Quarterly, 44 (1): 81-100.

Tappan, H., 1980. Haptophyta, Coccolithophores, and other Calcareous Nannoplankton. The paleobiology of Plant Protists. San Francisco, Freeman and Co.

Ter Borgh, M., Vasiliev, I., Stoica, M., Knežević, S., Matenco, L., Krijgsman, W., Rundić, L., Cloetingh, S., 2013. The isolation of the Pannonian basin (Central Paratethys): new constraints from magnetostratigraphy and biostratigraphy. Global and Planetary Change, 103: 99-118.

Ter Borgh, M., Stoica, M., Donselaar, M., Matenco, L., Krijgsman, W., 2014. Miocene connectivity between the Central and Eastern Paratethys: constrains from the western Dacian Basin. Palaeogeography, Palaeoclimatology, Palaeoecology, 412: 45-67.

Thomas, E., 1990. Late Cretaceous through Neogene deep-sea benthonic foraminifers (Maud Rise, Weddell Sea, Antarctica). Proceedings ODP, Scientific Results, 113: 571-594.

Tóth, E., 2008. Sarmatian (Middle Miocene) ostracod fauna from the Zsámbék Basin, Hungary. Geologica Pannonica, 36: 101-151.

Tóth, E., Görög, Á., 2008. Sarmatian foraminifera fauna from Budapest (Hungary). Hantkeniana, 6: 187-217.

Tóth, E., Görög, Á., Lecuyer, V, Moissette, P., Balter, B., Monostori, M., 2010. Paleoenvironment reconstruction of the Sarmatian (Middle Miocene) central Paratethys based on paleontological and geochemical analyses of foraminifera, ostracods, gastropods and rodents. Geological Magazine, 147: 299-314.

Vrsaljko, D., Pavelić, D., Miknić, M., Brkić, M., Kovacić, M., Hecimović, I., Hajek-Tadesse, V., Avanic, R., Kurtanjek, N., 2006. Middle Miocene (Upper Badenian/Sarmatian) paleoecology and evolution of the environments in the area of Medvednica Mt. (North Croatia). Geologica Croatica, 59: 51-63.

Whatley, R.C., 1995. Ostracoda and oceanic palaeoxygen levels. Mitteilungen aus dem Hamburgischen Zoologischen Museum und Institut, 92: 337-353.

Zlinská, A., Hudáčková, N., Koubová, I., 2010. Lower Sarmatian foraminifera from marginal marine environments in the Malacky vicinity (Vienna Basin). Geologické Výzkumy na Moravě a ve Slezsku, 16th Conference on Upper Tertiary, Brno: 104-106.

Zlinská, A., Zorn, I., Zágoršek, K., 2013. Foraminifers, ostracods and bryozoans from around Devínska Nová and Záhorská Bystrica (Slovak part of the Vienna Basin). Mineralia Slovaca, 45: 185-200. 